\title{
COMPETITIVE EFFECTS OF ANNUAL \\ WEEDS ON SPANISH PEANUTS
}

\author{
By \\ LOYD VERNON HILL \\ Bachelor of Science \\ Oklahoma State University \\ Stillwater, Oklahoma \\ 1956
}
Submitted to the faculty of the Graduate College of the Oklahoma State University
in partial fulfillment of the requirements
for the degree of
MASTER OF SCIENCE
August, 1969


OREMHOWA

STATE UNIVERSII

LLEPARY

NOV

COMPETITIVE EFFECTS OF ANNUAL WEEDS ON SPANISH PEANUTS

Thes is Approved:

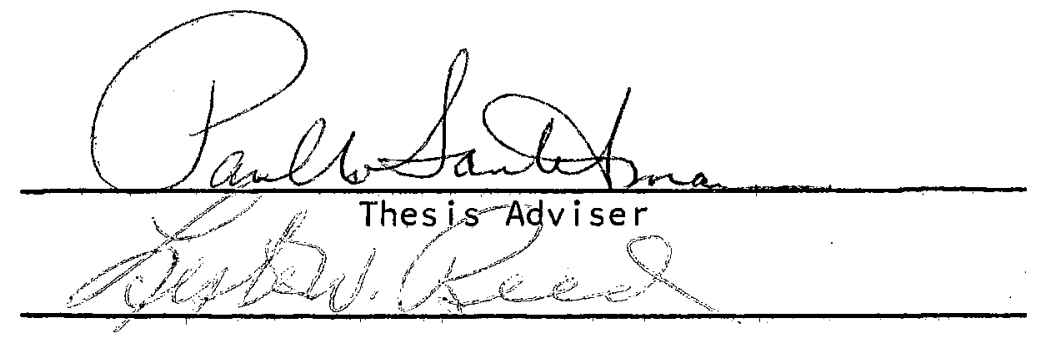

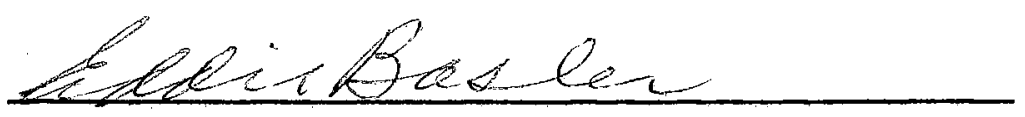

D.P. Acuham

Dean of the Graduate College

729964 


\section{ACKNOWLEDGMENTS}

Appreciation is extended to the author's major adviser, Dr. Paul $W$. Santelmann, for his time, consideration, and thoughtful advice and criticisms while working on this research project.

Appreciation is also extended by the author to the members of his committee, Dr. Lester Reed and Dr. Eddie Basler, for their assistance and needed advice.

The author extends his appreciation to the Agronomy farm superintendents, Mr. H. Myers and Mr. O. Stout, at Stillwater and Perkins, respectively, for the use of field equipment in conducting the field studies,

Credit is due to Mary, the author's wife, for her encouragement and patience while working on this research project. Appreciation is also extended by the author to his children, Wilma, April, Debra, Jane, and Jack, for their time and understanding during the furthering of his education.

The author sincerely thanks his father, Mr. Carl H. Hill, for his encouragement during the research study.

The author would like to express his gratitude to the Oklahoma Peanut Commission for the financial assistance used in this investigation. 
TABLE OF CONTENTS

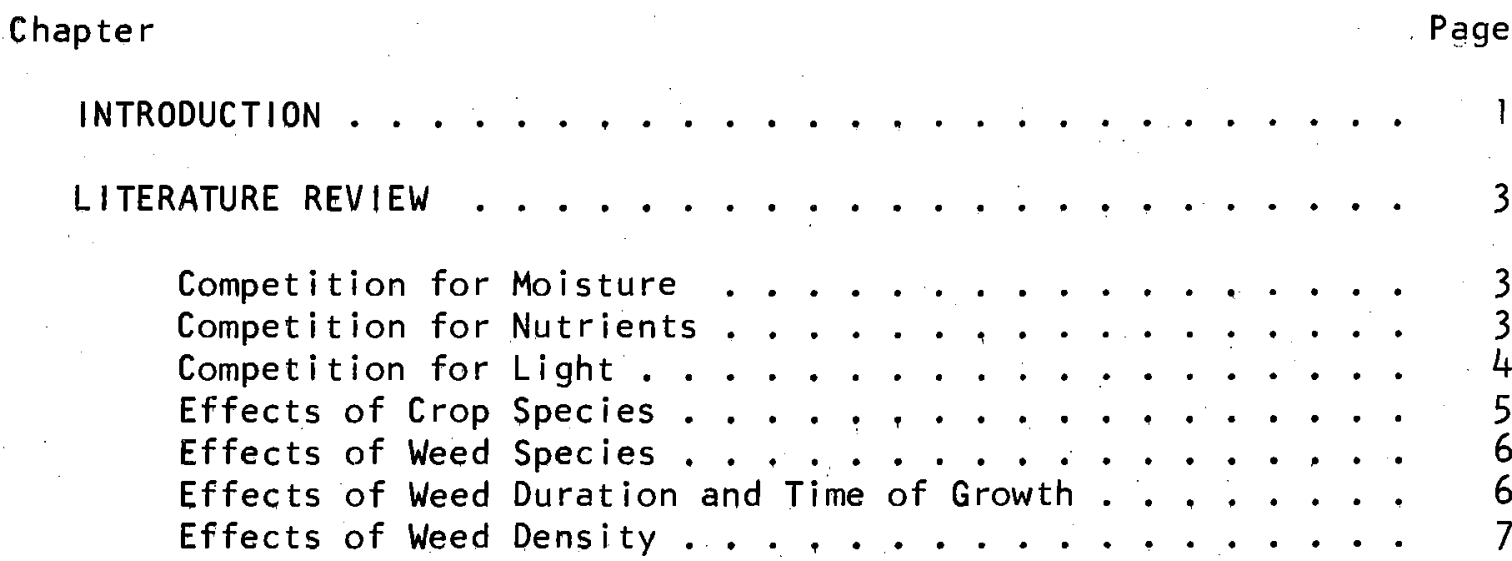

METHODS AND PROCEDURES ......................... 9

Field Study 1................... 9

Field Study 11 . . . . . . . . . . . . . . 11

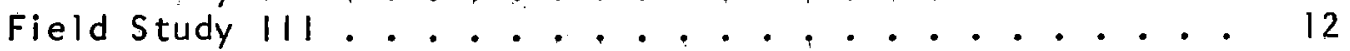

Greenhouse Study I.................. 12

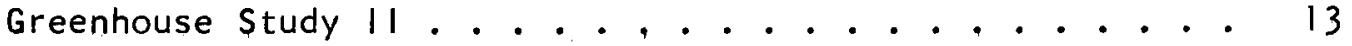

RESULTS AND DISCUSSION ............................ 15

Field Study 1 and Field Study 11 . . . . . . . . 15

Field Study lll................... 28

Greenhouse Study 1............... . . 34

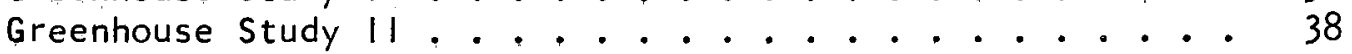

SUMMARY . . . . . . . . . . . . . . . . 42

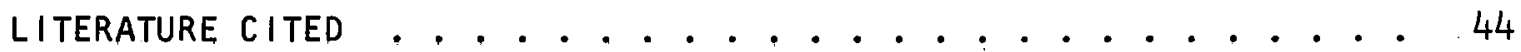

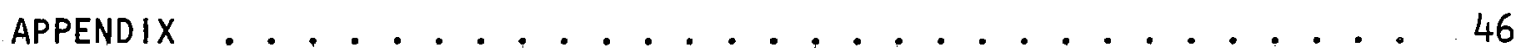




\section{LIST OF TABLES}

Table

Page

1. Mean Number of Blooms per Peanut Plant as Influenced by the Period and Length of Time Weeds Were Allowed to Grow in the Plots 47 Days After Planting. Field Study 1.......................

11. Yield of Peanuts (Nuts and Forage) and of Weeds as Influenced by the Period and Length of Time Weeds Were Allowed to Grow in the Plots.......... 48

111. Effects of Annual Weed Duration on Inches of Soil

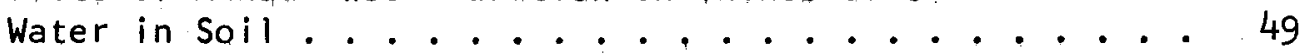

IV. Effects of Annual Weed Duration on Inches of Soil Water in 0 to $54 \mathrm{Inch}$ Soil Depth . . . . . . . 50

V. Yield of Peanuts (Nuts and Forage) and of Weeds as Influenced by Two Weed Species at Varying Densities . . 51

VI. Mean Nut and Forage Peanut Weight as Influenced by Two Weed Species at Varying Densities. Greenhouse Study I. . . . . . . . . . . . . . . 52

VII. Mean Forage Weight of Smooth Pigweed as Influenced by Growth with Peanuts. Greenhouse Study I. . . . . 53

VIII. Mean Crabgrass Forage Weight as Influenced by Growth with Peanuts and Crabgrass. Greenhouse Study I. . . . 54

1X. Effects of Time on Peanut, Crabgrass and Pigweed Forage Weight Grown at Different Densities. Greenhouse Study II. . . . . . . . . . . 55 
Figure

Page

1. The Effects of Annual Weeds on the Number of Blooms Per Plant 47 Days After Planting. Field Study 1. . . . . . 16

2. Influence of the Number of Weeks of Weed-Free Growth on the Yield of Peanuts. Field Study 1 and 11 ...... 17

3. Influence of the Number of Weeks of Growth with Weeds on the Yield of Peanuts. Field Study I and II....... 19

4. Influence of the Number of Weeks of Weed-Free Growth on the Forage Yield of Peanuts. Field Study $\mid$ and II,... . 21

5. Influence of the Number of Weeks of Growth with Weeds on the Forage Yield of Peanuts. Field Study I and II . . . 23

6. Influence of the Number of Weeks of Weeding on Weed Yield. Field Study 1 and II............. 24

7. Effects of Annual Weed Duration on Soil Water in 0 to 27 Inch Depth. Field Study II, . . . . . . . , 26

8. Effects of Annual Weed Duration on Soil Water in 27 to 54 Inch Depth. Field Study II........... 27

9. Effects of Annual Weed Duration on Soil Water in 0 to 54 Inch Soil Depth. Field Study II.......... 29

10. Effects of Two Weed Species at Different Densities on Peanut Yields. Field Study Ill .......... 31

11. Effects of Two Weed Species at Different Densities on Peanut Forage Yields. Field Study $\|1\|$. . . . . . . 32

12. Effects of Weed Density of Two Weed Species on Weed Yields. Field Study III............... 33

13. Effects of Two Weed Species at Varied Densities on Peanut Yields. Greenhouse Study I........... 35

14. Effects of Two Weed Species at Varied Densities on Peanut Forage Yields. Greenhouse Study I. . . . . . 36 
15. Effects of Competition of Weeds and Peanuts on Weed Dry Weight. Greenhouse Study 1............ 37

16. Effects of Peanut and Weed Duration on Dry Weight of Peanut Forage Yield. Greenhouse Study 11........ . 39

17. Effects of Peanut and Crabgrass Duration on Dry Weight of Crabgrass Yield. Greenhouse Study II . . . . . . . 4 40

18. Effects of Peanut and Pigweed Duration on Dry Weight of Pigweed Yield. Greenhouse Study II........... 


\section{INTRODUCTION}

One of the major problems in the production of Spanish peanuts, Arachis hypogaea L., is the control of weeds. Boswell (4) showed that annual weeds reduced the yields of Spanish peanuts as much as 40 to 44 percent. Weeds increase disease problems, increase hoeing cost, inhibit pegging, and severely interfere with harvest and curing of peanuts. Standard mechanical weed control procedures, such as cultivation and hoeing, may themselves cause many problems. For instance, the throwing of soil into the peanut row during cultivation (dirting) appears to increase the possibility of southern blight disease problems $(1,26)$. In addition, mechanical weed control practices are of limited use after peanuts begin pegging. As peanut growers tend to make greater use of herbicides, a knowledge of the nature of the competitive effects of annual weeds would enable them to obtain higher peanut yields. Chemical and mechanical weed control practices would be more effective when used before weed competition reduces peanut yields, but the point at which this occurs is not known at the present time. Growers could better evaluate the benefits of weed control practices if they knew the yield reductions caused by different stands of weeds as well as different species of weeds.

The purpose of this study was to (1) determine how peanut growth and yield are affected by weed growth of different durations during the growing season and at various stages of crop growth and (2) determine 
the effects of different densities of two annual weeds common to peanut. production in Oklahoma, 


\section{LITERATURE REVIEW}

Weeds compete directly with the crop for light, water, and nutrients. The extent of competition is altered by crop species, weed species, weed duration in crop, time of growth in crop, and weed den, sity.

\section{Competition for Moisture}

Available soil moisture is a major factor limiting plant growth and the ultimate crop yield produced. Soybean yield reductions due to annual weed infestations averaged $5 \%$ when soil moisture conditions during the growing season were either adequate for or severely limited for plant growth. Reductions were also small when moisture was limiting in early season and adequate later. When soil moisture was adequate until late July and then severely limiting until bean maturity, yield reductions from weed competition averaged 15\% (19). Blackman and Templeman (2), Staniforth and Weber (18), and Swan and Furtick (23) indicate that higher yield reductions due to weeds were associated with adequate early season moisture, Early season moisture apparently has the effect of establishing higher populations of weeds which later compete severely with the crop for available soil moisture.

\section{Competition for Nutrients}

Weeds are severe competitors with cultivated crops for all nutrients, but particularly for nitrogen, phosphorus, and potassium, which are often limiting factors in crop production. Greer (11) suggested that a means of measuring competition between weeds and crops is to 
determine their nutrient uptake. Munn and Barnes (15) have shown that certain weeds, when grown in competition with barley, were able to take up nitrogen at the expense of the crop. Blackman and Templeman (2) reported that in the presence of some weed species the nitrogen content of barley and oats was reduced. The addition of nitrogen fertilizer in every case raised the nitrogen level of the weedy crop to that of the weed-free crop which received no nitrogen. Phosphorus levels were also lowered by the presence of weedy plants while the content of potassium was not affected. Vengris, Colby, and Drake (24) compared the nutrient content of four weed species with corn. Results indicate that the weed species contained higher percentage of nutrients than did corn. On the dry weight basis at early maturity, the weeds contained approximately twice as much nitrogen, 1.5 times as much phosphorus and 3.5 times as much potassium as did corn. This study also indicated rough pigweed, Amaranthus retroflexus L., grown with corn had the ability to utilize forms of soil phosphates which were relatively unavailable to corn. Competition for Light

Competition for light occurs whenever one plant casts a shadow on another or within a plant when one leaf shades another leaf. Dawson (9) reported only one percent of the mid-day light energy reached the soil surface in sugar beet fields ten weeks after emergence of the crop. This study also suggested that the difference in competitive ability of lambsquarter, Chenopodium album L., and barnyardgrass, Echinochloa crusgalli (L.) Beauv., was due to the dense shade provided by lambsquarters. Knake and Slife (13) found that three to five weeks after corn and soybean emergence, 2.5 and 3.0 percent of the mid-day light energy reached the soil surface. At this light intensity giant foxtail, 
Setaria faberi Hurrm., that emerged after this time produced little or no dry matter and did not reduce crop yields. Blackman and Templeman's (2) and Donald's (10) work indicated that in years of normal rainfall, competition is mainly for light and is operative only when the weedy species are taller than the crop species. Nelson and Nylund (16) reported peas and annual weeds competed mainly for light. Brimhall (5) reported that the size of leaf of sugar beets was reduced by competition of weeds and indicated that light was a major factor of the competitive effect of weeds. The research of Knake and Slife (13) and of Dawson (9) showed that under certain conditions various crop species will provide enough competition for light to successfully control weeds.

\section{Effects of Crop Species}

Giant foxtail that began growing with the crop and left to maturity reduced corn yield $13 \%$ and soybean yield $27 \%$ (13). Moolani, Knake, and Slife (14) reported yield reductions from a 4 to 6 inch band of smooth pigweed, Amaranthus hybridus L., in the crop row averaged $39 \%$ for corn and $55 \%$ for soybeans, based on a three year average. The increase in pigweed dry matter about equalled the decrease in dry matter from corn. Pigweed grew taller than soybeans and the dry weight of soybeans plus pigweed was one and one-third times that of weed-free soybeans. The results indicated the growth characteristics of the crop will determine its competitive ability. Staniforth's (19) work using different corn hybrids in competition with yellow foxtail, Setaria lutescens (Weigel) F. T. Hubb., showed yield reduction per hundredweight of foxtail for the late maturing hybrid was approximately double those of the early adapted hybrid. This study indicated that different varieties of the same crop species are effected differently by weed competition. 


\section{Effects of Weed Species}

Blackman and Templeman (2) working with cereal crops showed white charlock, Raphanus raphanistrum, to be more aggressive than yellow charlock, Brassica arvensis, which in turn brought about greater depressions in yields than field poppy, Papaver rhoeas. The yield of sugar beets was reduced significantly more by rough pigweed as compared to green foxtail, Setaria viridis L., at the same density (6). Staniforth (20) suggested the difference in giant foxtail, yellow foxtail, and green foxtail competitive effects on soybeans was due entirely to differences in growth and mature plant yield among the species. The study also indicated the greater competitive effect of velvetleaf, Abutilon theoprasti, on soybeans apparently resulted from a greater shading effect. Vengris (25) suggested the difference between rough pigweed and yellow foxtail was due to the development patterns and mode of competition. The pigweed grew faster in the spring and, thus, competes more than foxtail with the cultivated crop. Dawson (9) stated uncontrolled lambsquarters reduced yields of sugar beets $94 \%$ while uncontrolled barnyardgrass reduced yields only $49 \%$. Mixed populations of barnyardgrass and lambsquarter reduced yields about $70 \%$. No significant difference was found between common morningglory, Imopea purpurea (L.) Roth., and ivyleaved morningglory, Imopea hederacea (L.) Jacq., or both species together on the yield of soybeans (27).

\section{Effects of Weed Duration and Time of Growth in Crop}

Burnside and Wick's (7) research with sorghum showed that yields were decreased each week when pigweed, foxtail, and crabgrass, Digitaria spp., were not removed for $4,5,6$, or 8 weeks after planting. This study also showed sorghum yields were reduced when weeds were removed 
only during the first two weeks; when weeds were removed the first 4,6 , or 8 weeks only, sorghum yields were not different from plots weeded every week. Dawson's (8) research with field beans showed barnyardgrass, lambsquarters, and pigweed reduced yields of beans the most when the weeds emerged with the crop. Weeds emerging 5 to 7 weeks after planting did not reduce bean yields. Further work of Dawson (9) with sugar beets showed that barnyardgrass and lambsquarters did not reduce final yields unless weeds grew for more than 8 to 12 weeks after beets were planted. When beets were weeded weekly for varied periods after planting, yields increased until a maximum was reached after 12 weeks. Giant foxtail reduced the yield of corn and soybeans when seeded with the crop but did not when seeded three weeks after the crop was planted (13)

\section{Effects of Weed Density}

Moolani et al. (14) in a three year study with smooth pigweed at varying densities in corn showed that one weed every. 10 inches in the row reduced corn yields significantly and a weed every inch in the row further reduced yields. In the same study one pigweed plant every 20 inches in the soybean row reduced the yield significantly and a pigweed every, inch also further reduced yields. Brimhall, Chamberlain, and Alley (6), working with rough pigweed and green foxtail in competition with sugar beets, showed that root yields were affected tremendously by different weed densities. The weed-free check yield of 22.5 tons per acre contrasted with 3.4 tons per acre for the treatment with the heaviest weed infestation. All densities of pigweed reduced the beet yield significantly from that of the check. Green foxtail densities of less than one plant per sugar beet in the row did not reduce the beet 
yield significantly from that of the check, but densities greater than one green foxtail per beet reduced yields significantly. Wilson and Cole (27), using common morningglory and ivy-leaved morningglory, reduced soybean yields significantly at all weed densities. Yield reductions varied from 12 percent of the check with one morningglory every two feet of soybean row to 44 percent with 8 morningglory per foot of row. Nelson and Nylund's (16) work with peas in competition with white mustard, Brassica kaber (DC) L. C. Wheeler, showed that one mustard plant per square foot had little effect on growth and yield of peas. However, three mustard per square foot reduced pea yield by 26 percent when allowed to compete with peas for five weeks, and reduced pea yield by 58 percent after ten weeks of competition. Pafford (17) working with Palmer's pigweed, Amaranthus palmeri Wats., in competition with grain sorghum showed reductions of yield ranging from 817 pounds per acre as the result of one pigweed every eight feet of sorghum row to 3,902 pounds per acre reduction for the uncultivated check. 


\section{METHODS AND PROCEDURES}

\section{Field Studies}

Field studies were conducted on the Oklahoma State University Agronomy Research Station near Perkins, Oklahoma on a Vanoss sandy loam soil during the summers of 1966, 1967, and 1968. All field studies were conducted as randomized block designs with all plots consisting of four 36 to 40 inch rows. All plots were seeded to large Spanish peanuts, Arachis hypogaea L., variety Argentine, at the rate of 60 pounds per acre. Peanut nut yields and forage yields were obtained from the two center rows of each plot, The plots were dug with a two row peanut digger and shaker. The peanuts from each plot were bundled and allowed to air dry in the field. They were then threshed with a stationary peanut thresher. Forage yields were determined by determining the total plant weight from each plot before threshing and then subtracting the nut weight after threshing. Peanut yields are expressed in pounds of unshelled nuts per acre. Peanut forage and weed weights are expressed in air dried dry matter as tons per acre. Experimental results were evaluated by an analysis of variance, and differences among treatments were tested with Duncan's new multiple range test at the $95 \%$ level of probability $(22)$.

Field Study I

Peanuts were seeded June 13, 1966 in 36 inch rows, with 5 replica- 
tions and a plot length of 20 feet. The following treatments were assigned at random to plots within each replication: (a) kept weed-free all season, (b) weeds left all șeason, (c) weeds initially removed 2, 3, $4,5,6,7$, or 8 weeks after planting and plots then kept weed-free, and (d) plots kept weed-free after planting, but weeding stopped 2, 3, 4, 5, 6 , or 8 weeks after planting.

Smooth pigweed and crabgrass were seeded in the plots to supplement the natural weed population in order to insure a uniform heavy stand of weeds in the experimental area. The weeds were seeded with a hand cyclone seeder and lightly covered with a hand garden rake.

Weeding at weekly intervals of appropriate treatments until harvest was done by shallow hoeing and hand pulling.

Approximately 1 inch supplemental overhead irrigation was applied June 2l, July 2, and August 9 for approximately 4 hours. The irrigation was applied to insure that moisture was not a limiting factor in the competition study.

Due to an infestation of corn earworm, Heliothis zea, plots were sprayed with $1,2,3,4,10,10$-hexachloro-6, 7-epoxy-1, 4, 4a, 5, 6, 7, 8, 8a-octahydro-1, 4-endo-exo-5, 8-dimethanonephthalene (dieldrin), at the rate of 1 quart per 50 gallons of water/A on July 28, August 1 , and August 17.

The number of blooms per peanut plant was counted on 5 plants from either of the two center rows of plots 47 days after planting to determine the growth retardation of peanuts as influenced by weeds. Weed yields were taken 37 days after planting from a 2 square foot area in the outside rows and 117 days from 9 square foot area between the center rows of appropriate plots; samples were air dried before weighing. Pea- 
nut yields and forage yields were taken from two 14.4 foot rows of each plot. The plots were dug 0ctober 11 and threshed 0ctober 22.

\author{
Field Study II
}

Peanuts were seeded May 26, 1967 in 36 inch rows utilizing 4 replications and a plot length of 50 feet. The same treatments were used as in Field Study $\mathrm{I}$ and randomly assigned to plots within each replication.

Smooth pigweed and large crabgrass were seeded with a hand cyclone seeder May 26 and covered lightly with a hand garden rake. Weeding was done as in 1966.

A weed density count was taken 32 days after planting to determine the weed population in the different treatments. The counted area was 16 square feet taken over the two center rows of the plot.

Two soil moisture tubes, 2 inches in diameter, were driven to a depth of 48 inches below the soil surface in 3 replications. The tubes were placed in the center rows at least 10 feet from the ends of the plot. Moisture was determined in the following treatments: weed-free, not weeded, weeded for 3 and 6 weeks, and weeded after 3 and 6 weeks. Soil moisture was determined by the neutron probe method $49,55,68,77$, $84,91,98$, and 110 days after planting.

Due to an extended dry period, I inch of supplemental irrigation was applịed August 18 by overhead sprinkling for 4 hours.

Weed yields were taken 120 days after planting from a 9 square foot area between the center rows of appropriate plots; samples were air dried before weighing. Peanut yields and forage yields were obtained from two 40 foot rows of each plot. The plots were dug September 30 and bundled the same day. The peanuts were field cured until october 12 
when replications 1 and 2 were threshed. Replications 3 and 4 were threshed October 13 .

Field Study 111

Peanuts were seeded June 6, 1968 in 40 inch rows. The plots were 25 feet long, replicated four times. Weed density treatments were as follows: (a) weed-free, (b) one large crabgrass every 1, 2, 4, 6, or 8 feet of peanut row, and (c) one smooth pigweed every 1, 2, 4, 6, or 8 feet of peanut row.

The crabgrass and pigweed were seeded in the greenhouse June 4 in soil filled flats, divided by 2 inch square dividers. The weeds were thinned to three plants per square before placing in the peanut row at the desired density on June 17. Weeds were then thinned in the field to one plant per square on June 22 .

The experiment was irrigated by overhead sprinkler irrigation June 20, July 4, and July 27 to insure weed survival.

Weed yields were taken from treatments ( $b$ and $c$ ) by harvesting weeds in the two center rows of the appropriate plots and air drying before weighing on November 1. Peanut and forage yields were taken from 25 feet of the center rows of each plot. Peanuts were dug 0ctober 26 and air dried until November 1 when bundles were weighed. The plots were threshed November 9.

\section{Greenhouse Study 1}

Peanuts and weeds were planted in 10 inch pots and placed in greenhouse November 28, 1966 to study the competitive effects of peanuts, smooth pigweed, and crabgrass. A randomized block design was used with 
4 replications with the following treatments: (a) 1 and 2 peanuts per pot, (b) $1,2,3$, or 4 pigweeds per pot, (c) 1, 2, 3, and 4 crabgrass per pot, (d) 1 peanut plus 1, 2, 3, or 4 pigweeds per pot, (e) one peanut plus $1,2,3$, or 4 crabgrass per pot, (f) two peanuts plus 1, 2, 3, or 4 pigweeds per pot, and (g) two peanuts plus 1, 2, 3, or 4 crabgrass. A 10 inch pot has approximately 0.5 square feet surface area; thus, 1 peanut plus 4 weeds approximates a heavy weed population in the field.

The pots were watered daily and fertilized with 21-19-17.5 fertilizer every two weeks. Artificial fluorescent lighting was used to have a 14 hour day for the duration of the study.

The pots were harvested March 10, 1967 by cutting off the peanuts, crabgrass, and pigweeds at ground level and drying them before weighing. The nut yields from the peanuts were taken from nuts produced in each pot.

\section{Greenhouse Study II}

A study was designed to evaluate the competitive relationship of peanuts and weeds with respect to time. Peanut and weeds were planted February 18, 1967 in 10 inch pots. The design was a split plot design. with time of harvest as main plot and weed and peanut density as subplot treatments. The experiment was replicated four times with the following treatments: (a) 1 or 2 peanuts, (b) 1 or 2 crabgrass, (c) 1 or 2 pigweed, (d) I peanut with 1 pigweed, and (e) I peanut with I crabgrass per pot. Six different dates of harvest were used as follows: $2,4,6,8$, 10 , and 12 weeks after planting of peanuts. The pots were watered daily and fertilized with 21-19-17.5 fertilizer weekly. Artificial fluorescent lighting was used in addition to natural light to retard pigweed 
flowering so that a day length of 14 hours was used. The plants were harvested by cutting off plants at ground level and oven drying for 12 hours at $90^{\circ} \mathrm{C}$. before weights were taken. 


\section{RESULTS AND DISCUSSION}

The field studies conducted during the summers of 1966 and 1967 were established to determine the competitive effects of large crabgrass and smooth pigweed on Spanish peanuts with respect to weed duration and time of infestation. In 1966, an initial weed population of 5.1 pigweed, 11.3 crabgrass, and 2.3 peanuts per square foot in the peanut row was observed 27 days after planting. In 1967 the initial weed population was slightly higher than in 1966 since 7.2 pigweed, 12.2 crabgrass, and 3.4 peanuts were found per square foot of the peanut row.

The average number of blooms per plant 47 days after planting was not significantly affected unless weeds were allowed to grow in competition with peanuts for 5 weeks or more (Figure $1 A$ ). If peanuts were weeded for 2 to 8 weeks, after which times weeds were allowed to grow unrestricted, the average number of blooms per plant was significantly greater if peanuts were weeded for 3 weeks as compared to those not weeded and plots weeded only 2 weeks (Figure 1B). Thus, if weeds were allowed to grow in the crop for more than 4 weeks or weeds not removed after 2 weeks, weed competition appeared to suppress the number of blooms on peanut plants.

Peanut yields in 1966 (Figure 2) were obtained from plots which were kept weed-free for varying periods of time; then weeds were allowed to come in and grow unrestricted until harvest. Peanut yields from the weed-free plots were significantly different from all other treatments. Weeds which were allowed to grow after the plots were kept weed-free for 


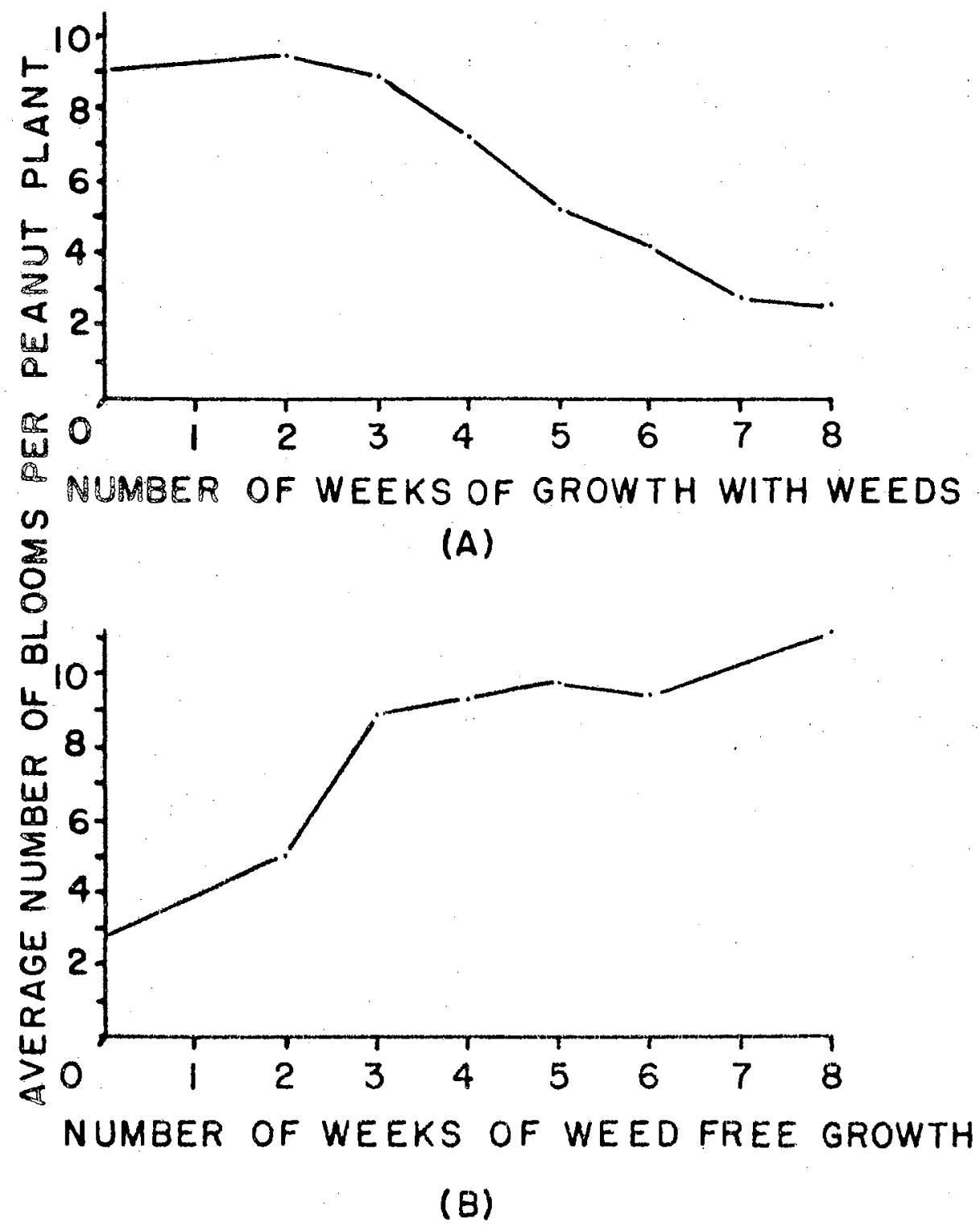

Figure 1. The Effect of Annual Weeds on the Number of Blooms per Plant 47 Days After Planting. Field Study I (1966) 


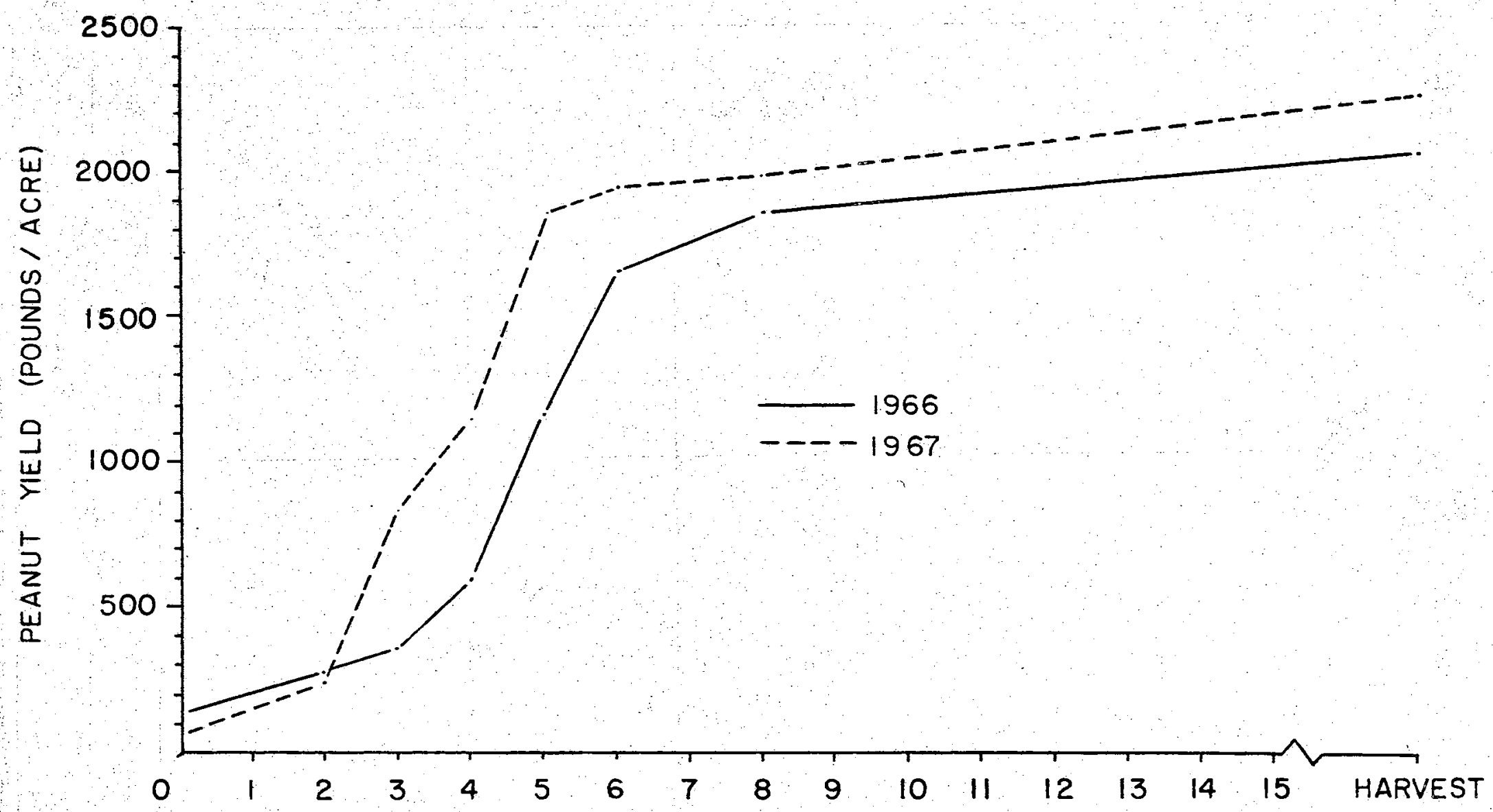

Figure 2. Influence of the Number of Weeks of Weed-Free Growth on the Yield of Peanuts. Field Study 1 and II 
6 or 8 weeks reduced peanut yields less than weeds which grew after 2, 3,4 , or 5 weeks of weed-free growth. The yields of peanuts kept weedfree for 4 or 5 weeks were significantly different from each other and both were significantly different from all other treatments kept weedfree for varied periods of time. The yield of peanuts which had weed growth after 3 weeks of weed-free growth was greater than the weedy check; however, the yield of peanuts kept weed-free for only two weeks was not different from the weedy check.

In 1967 weeds which grew after peanuts were weed-free for 5, 6, or 8 weeks did not reduce peanut yields significantly as compared to the yield of peanuts kept weed-free for the entire season. The results of both this study and the 1966 study show that weeds must be controlled the first 5 to 6 weeks after planting in order to obtain maximum yields. Weeds which emerge 5 to 6 weeks after planting will make enough growth to interfere with the harvesting and curing of peanuts but will not significantly compete with the peanuts. The yield of peanuts kept weedfree for only 2 weeks was not significantly different from the yield of peanuts not weeded the entire season. Peanuts weeded for 3 or 4 weeks produced significantly more peanuts than those weeded for 2 weeks and peanuts not weeded.

Peanut yields in. 1966 when weeds were allowed $2,3,4,5,6,7$, or 8 weeks of growth and then the plots kept weed-free until harvest are shown in Figure 3. Peanuts kept weed-free the entire season produced significantly more peanuts than other treatments. Weeds which grew in peanuts for 6,7 , or 8 weeks before removal reduced peanut yields significantly more than the yield of peanuts in which weeds grew only 2,3 , 4 , or 5 weeks before removal. Peanuts not weeded produced significantly 


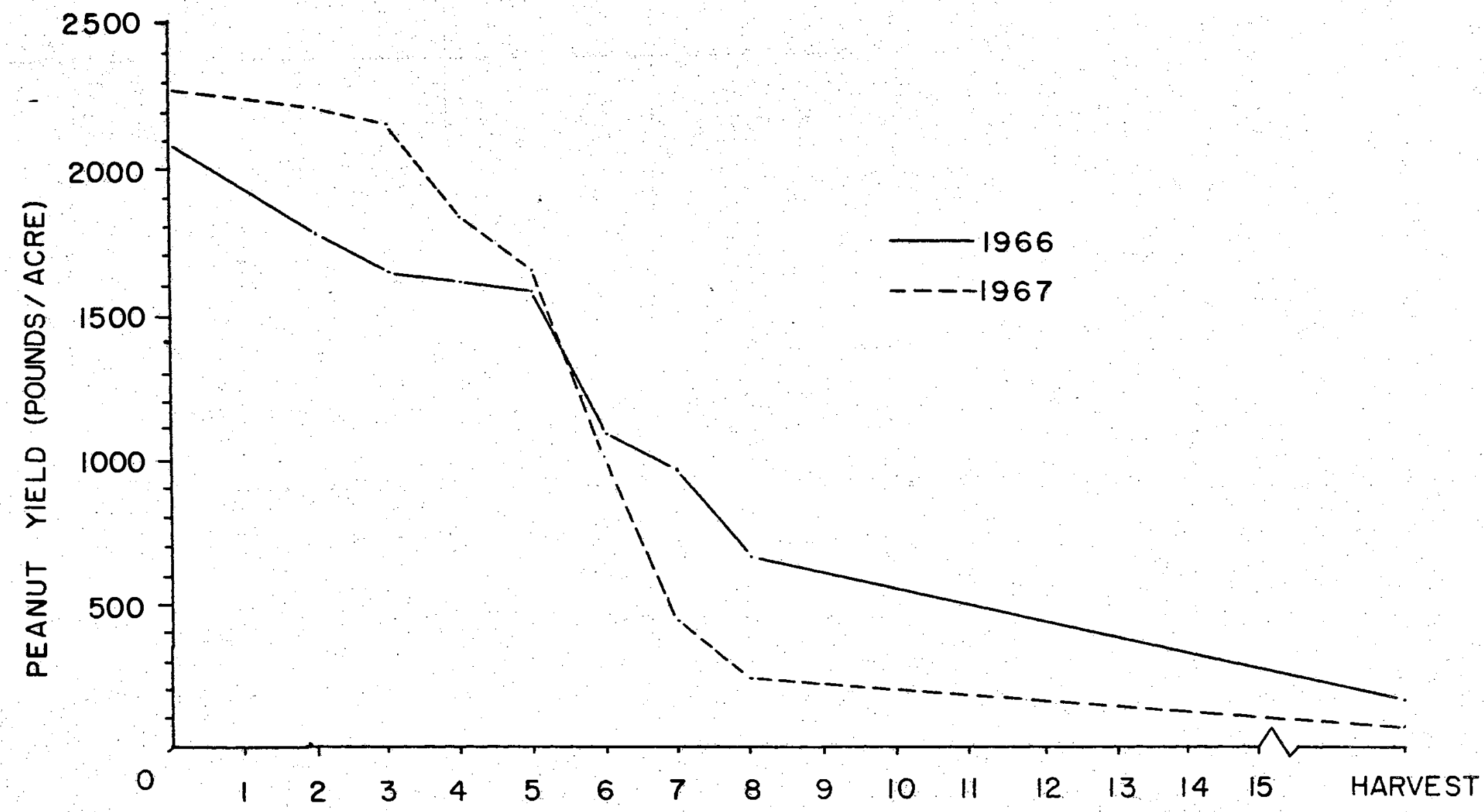

Figure 3. Influence of the Number of Weeks of Growth with Weeds on the Yield of Peanuts. Field Study $I$ and $I I$ 
less yield than peanuts weeded after 8 weeks, which in turn produced less yield than peanuts weeded after 6 or 7 weeks of growth with weeds. Peanuts weeded after 2 to 4 weeks did not yield differently.

Yields of peanuts from the same treatments in 1967 were reduced significantly after 5 to 8 weeks of growth with weeds. No significant peanut yield reduction occurred between peanuts which were weedy for 2 , 3 , or 4 weeks as compared to the peanut yield of the weed-free check, but all yields were significantly higher than the yields of peanuts which were weedy for 6 or more weeks. The yield of peanuts weeded after 6 weeks was significantly higher than peanuts which had weeds for longer duration. No significant difference was shown between the yield of peanuts weeded after 7 or 8 weeks and peanuts not weeded. The results of this study and the 1966 data indicate cultivation and postemergence herbicides would be most beneficial when applied within 3 weeks of planting.

Peanut forage yields (Figure 4), in 1966, where peanuts were weedfree for $2,3,4,5,6$, or 8 weeks after planting, showed significant reduction due to weeds which emerged after 6 weeks. No significant difference in peanut forage yield was shown if the peanuts were kept weedfree for 2 weeks, as compared to the peanut forage yield of the weedy check. There were significant increases in forage yields of peanuts weeded for $2,3,4$, and 5 weeks, but no significant difference between 5 and 6 weeks of weed-free growth. No significant difference was shown between the forage yield of peanuts weeded for 8 weeks and the yield of peanuts kept weed-free the entire season. The forage weight of similar peanuts in 1967 showed significant yield reductions due to weeds which emerged after 4 weeks. No significant difference between forage yields 


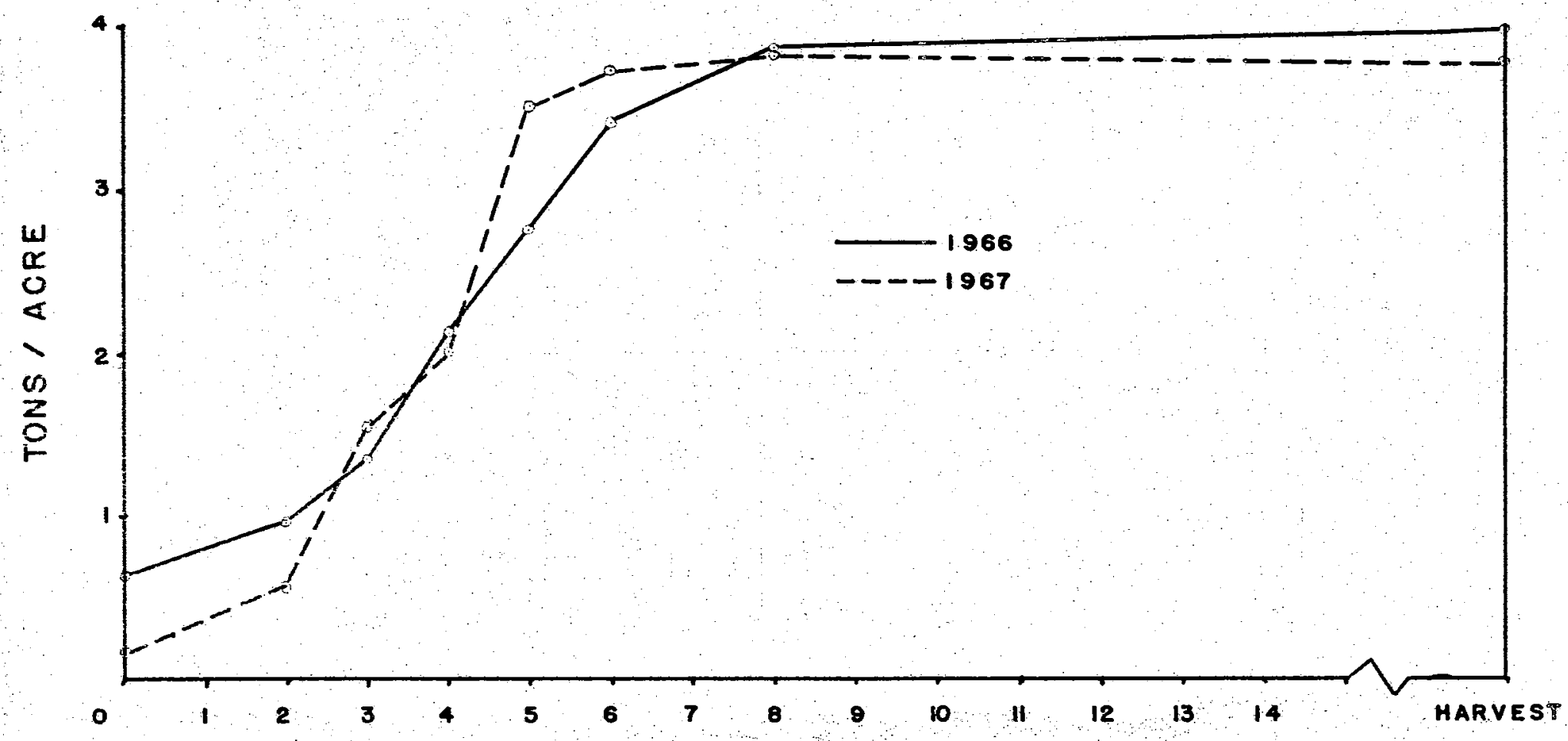

Figure 4. Influence of the Number of Weeks of Weed-Free Growth on the Forage Yield of Peanuts. Field. Studies 1 and 11 
of peanuts weeded for 3 or 4 weeks was shown; however, both yields were significantly lower in forage yield when compared to yields of peanuts weeded 5,6 , or 8 weeks and weed-free peanuts. Peanuts weeded for 3 weeks produced a significantly higher peanut forage yield than peanuts weeded for 2 weeks and the weedy peanuts, which were not significantly different.

Peanut forage yields in 1966 from plots which were weeded after 2, $3,4,5,6,7$, or 8 weeks (Figure 5) showed no significant forage yield reduction until weeds had grown in peanuts for 6 weeks. The forage yields of peanuts weeded after 6,7 , or 8 weeks and peanuts not weeded produced significant decreasing yields of peanut forage. Peanut forage yields from similar treatments also in 1967 showed a significant forage yieldi reduction when weeds grew for 6 weeks in peanuts. The forage yield of peanuts weeded after $2,3,4,5$, or 6 weeks of growth with weeds was not significantly different; however, their yields were significantly higher than the yield of peanuts weeded after 7 or 8 weeks and those not weeded.

Weed yields in 1966 (Figure 6) are shown as ton/A of weeds produced in peanuts weeded for $2,3,4,5,6$, or 8 weeks; after which times, weeds grew unrestricted until harvest. The weed yield was significantly reduced if peanuts were weeded for 5,6 , or 8 weeks after planting when compared to the yield of weeds produced in the weedy check. This shows peanuts kept weed-free by clean cultivation or herbicide practices for 5 or more weeks will compete successfully with weeds which emerge later in the growing season. However, weeds present in peanuts late in the season would interfere with harvesting and curing of peanuts. Weed yields the second year showed that peanuts grown weed-free for 3 weeks signifi- 


$$
\begin{array}{r}
1966 \\
-1967
\end{array}
$$

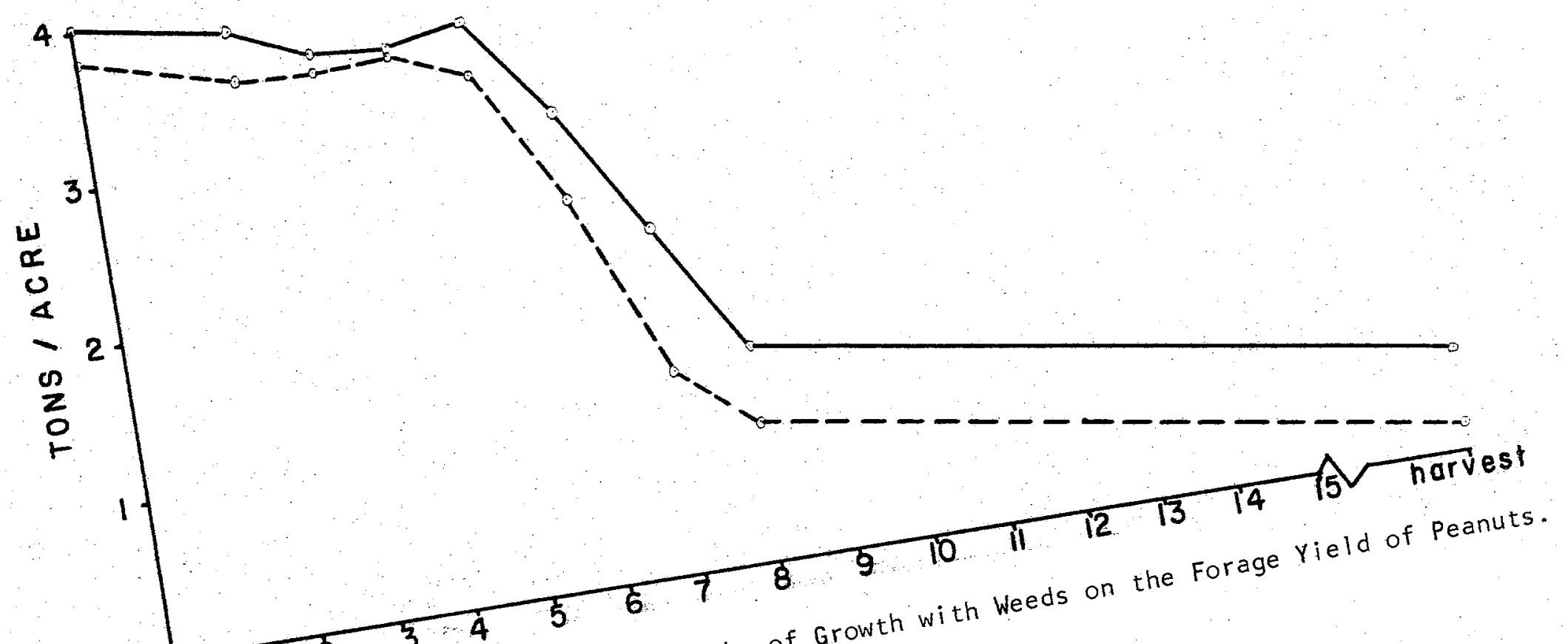

Figure 5. Influence of the Number of 11 


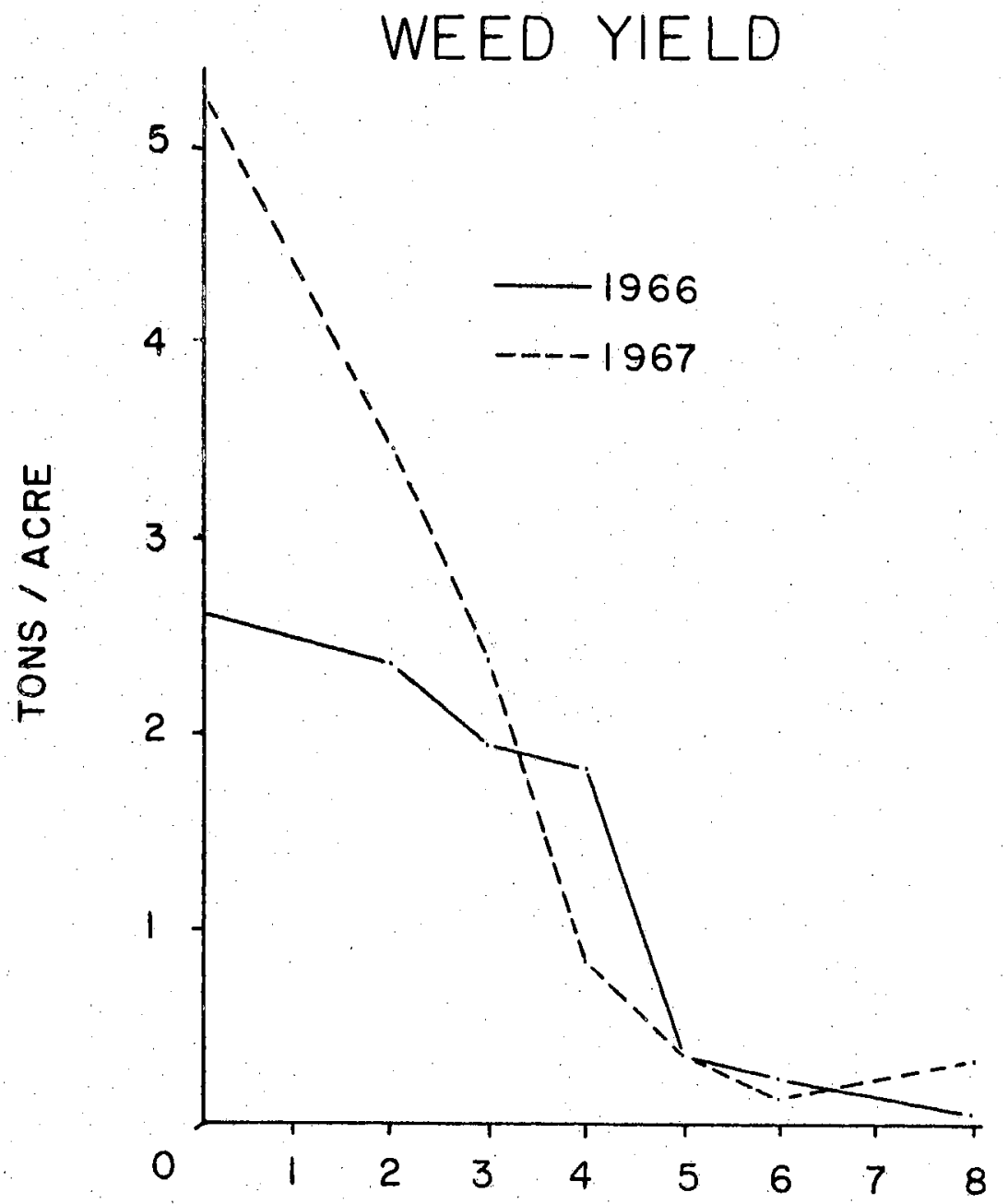

Figure 6. Influence of the Number of Weeks of Weeding on Weed Yield. Field Studies 1 and II. 
cantly reduced the tons of weed top growth produced when compared to weeds produced in weedy check. Peanuts weeded for 5, 6, or 8 weeks did not produce a significant tonnage of weeds when compared to the weedfree peanuts; however, the weeds present would hamper harvesting. Soil moisture shown as inches of soil water was determined at 6 , $12,18,24,36$, and 48 inch depths in 1967. Statistical analysis was conducted using the inches of soil water present in the 0 to 27,27 to 54, and 0 to 54 inch depths. Missing plot data was utilized for moisture readings from the third replication of peanuts weeded for 3 weeks at the 91,98 , and 110 day readings due to a water accumulation during irrigation 85 days after planting. Weed competition did not appear to cause a significant difference in soil water at the 0 to 27 inch depth (Figure 7), except at 84 days after planting, at which time peanut plots weeded after 6 weeks had significantly more soil water than did other treatments. Peanut plots which were weed-free and those weeded after 3 weeks had significantly more soil water in the profile as compared to peanut plots of the weedy check, and those weeded for the first 3 weeks after plànting.

Soil water in the 27 to 54 inch depth decreased as the season progressed (Figure 8), notwithstanding 1.75 inches of irrigation applied 85 days after planting and 2.8 inches of rainfall which fell between 101 and 105 days after planting. Peanut plots which were weed-free, weeded after 3 or 6 weeks, and weeded for 6 weeks did not differ significantly in soil water when compared to those not weeded at any date readings were taken. Plots which were not weeded for the entire season had significantly less soil water than those which were weeded after 3 and 6 weeks, at all dates which readings were taken. Peanut plots kept weed- 


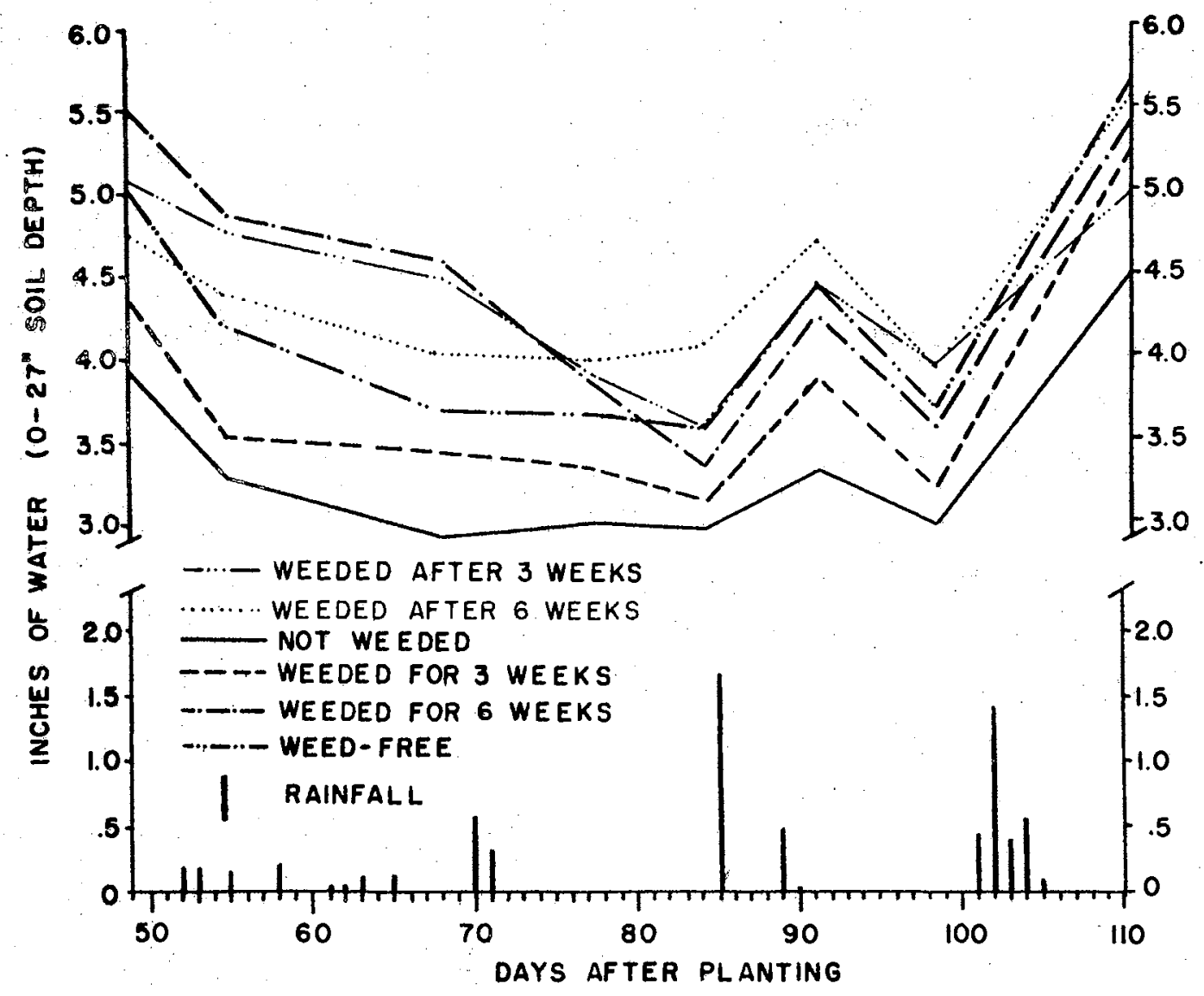

Figure 7. Effects of Annual Weed Duration on Soil Water in. $0-27$ Inch Depth. Field Study 11 


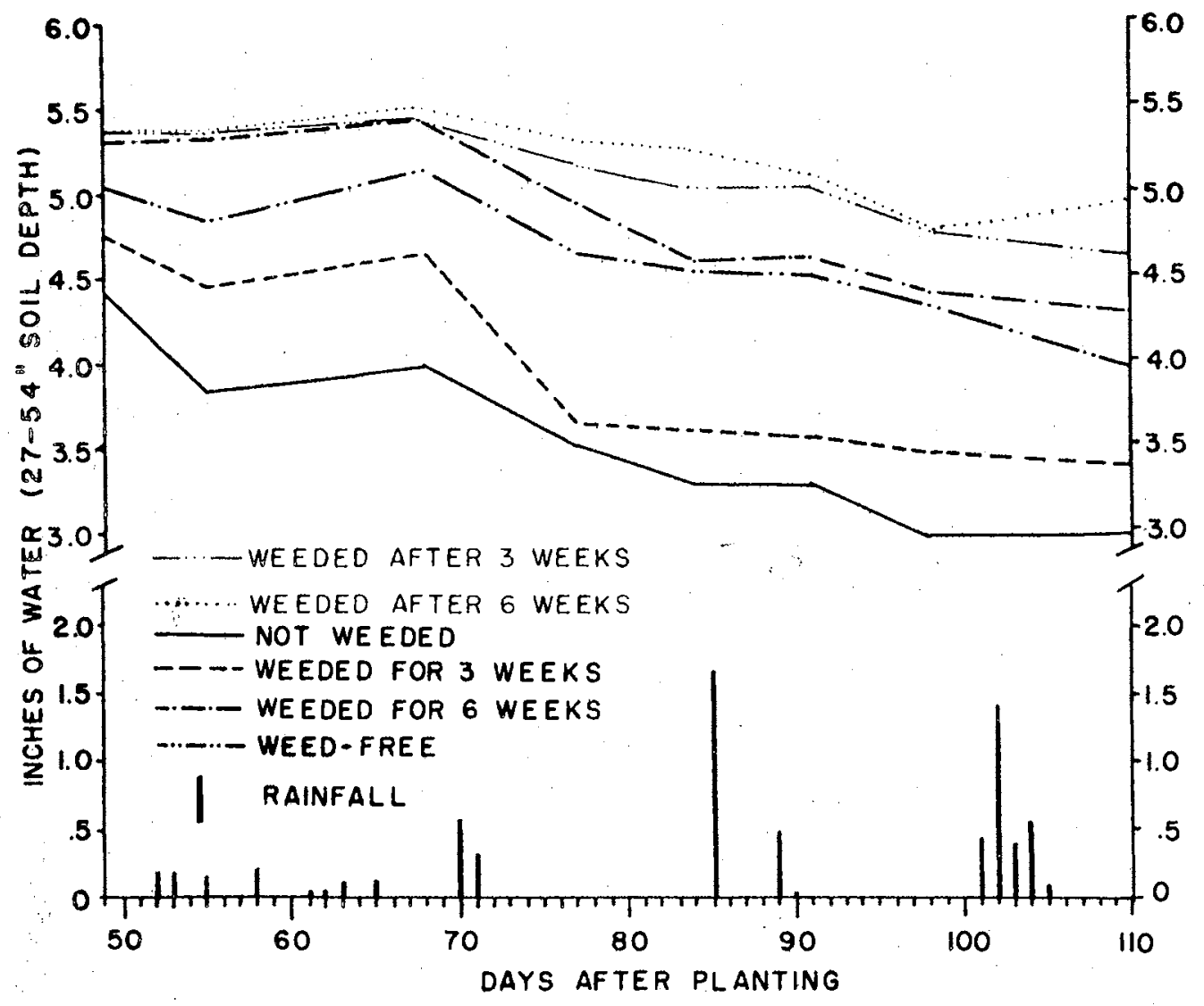

Figure 8. Effects of Annual Weed Duration on Soll Water in 27-54 Inch Depth. Field Study 11 
free all season had significantly more soil water than did peanuts of the weedy check 55, 68, 98, and 110 days after planting. The plots of peanuts weeded for 6 weeks had significantly more soil water than did the plots of peanuts not weeded.

The soil water present in 0 to 54 inch depth (Figure 9) shows no significant difference in any reading date between plots in which peanuts weeded after 3 or 6 weeks, weed-free, and weeded for 6 weeks. The soil water did not differ significantly between plots in which peanuts were weeded for 3 weeks and plots which were not weeded at any date readings were taken. The plots in which peanuts were weed-free and not weeded were significantly different in soil water 49 and 110 days after planting. Peanut plots which were weeded for 6 weeks had significantly more soil water than did those not weeded $49,55,68$, and 110 days after planting.

This data shows that peanuts growing in competition with weeds have less available soil water per plant. The data also indicates that peanuts which grew for the first 6 weeks after planting with weeds do not recover from the competitive effects of weeds to adequately use soil water when compared to peanuts which were weed-free the entire season,

Field Study III

In 1968 plots were established to determine the effects of large crabgrass and smooth pigweed at different densities on the growth of Spanish peanuts.

The results of this study may have been affected by the accidental treatment with trifluralin (a, a, a-trifluro-2, 6-dinitro-N, N-dipropyl$p$-toluidine) at the rate of one-half pound per acre. Weeds appeared to 


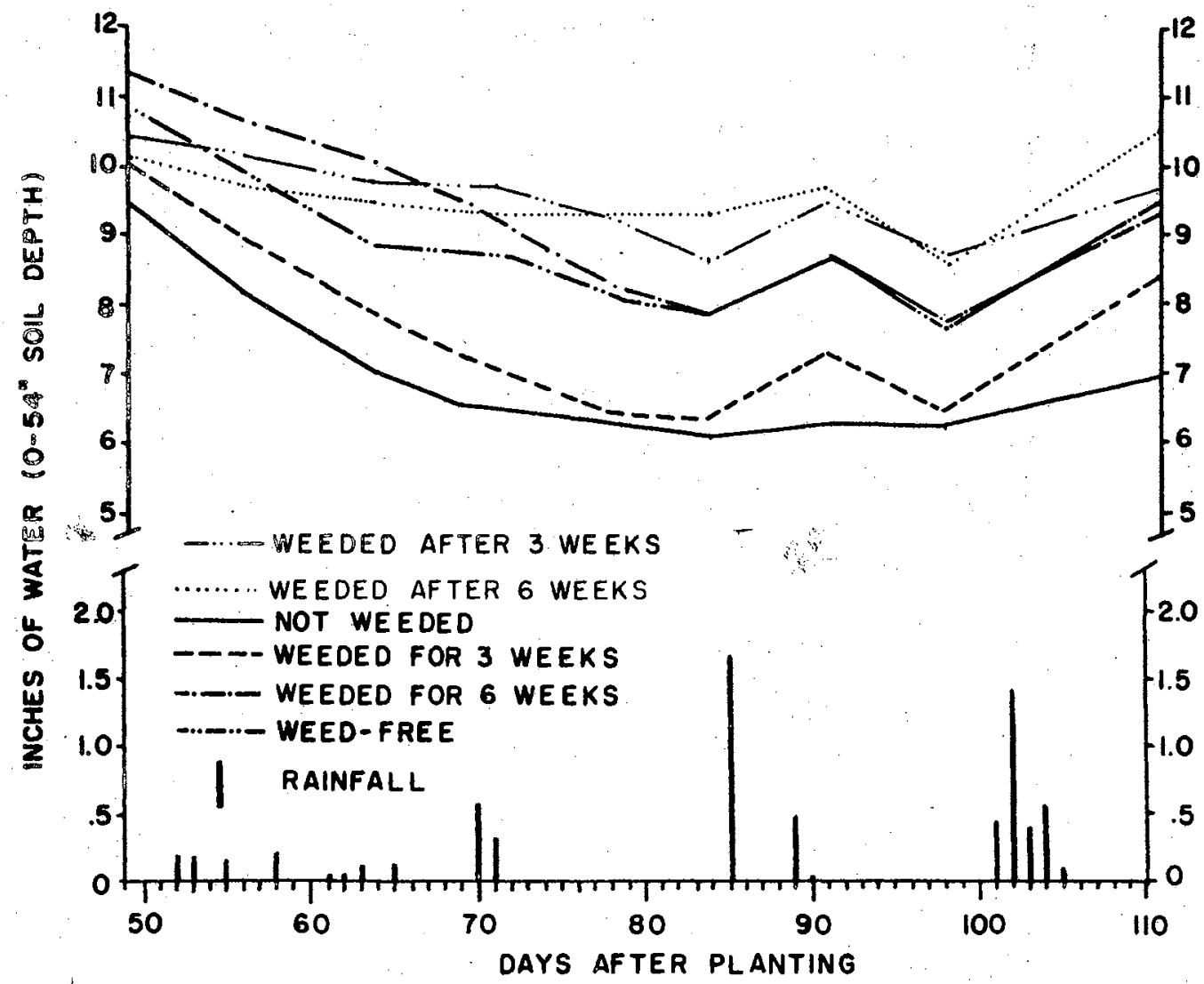

Figure 9, Effects of Annual Weed Duration on Amount of Soil Water in 0-54 Inch Depth. Field Study 11 
have been hampered in laterial root development in the upper surface of the soil.

The peanut yields were reduced as density of both large crabgrass and smooth pigweed increased (Figure 10). Both species of weeds reduced the yields of peanuts significantly when a weed density of one weed every one or two feet of row was allawed to develop. No significant peanut yield reductions were shown between plots with densities of one pigweed or crabgrass plant every 4,6 , or 8 feet of row as compared to the weed-free peanuts. Peanut yields were slightly lower when grown with pigweed when compared to yield of peanuts grown with crabgrass at the same density.

Peanut forage yields (Figure ll) showed significant yield reductions when a crabgrass plant grew at density of one weed every 1 or 2 feet of peanut row. Peanut forage yields were reduced when pigweed plants grew at densities of one weed every 1, 2, or 4 foot of peanut row. Pigweed which grew at a density of one weed every 1, 2 or 4 feet reduced peanut forage yields significantly more than did crabgrass at the same density. Thus, the forage data shows that smooth pigweed competes more severely than large crabgrass at the same density, apparently due to the shading effect of the pigweed plant.

The yields of pigweed or crabgrass (Figure 12) shows that the tonnage of weeds increased as weed densities increased in the peanut row. The pigweed or crabgrass produced in peanuts when a weed grew 6 feet apart produced significantly more tonnage than the weed-free check, one pigweed every foot yielded significantly more weeds than peanuts which had a pigweed every 6 foot, and one crabgrass every foot produced signi- 


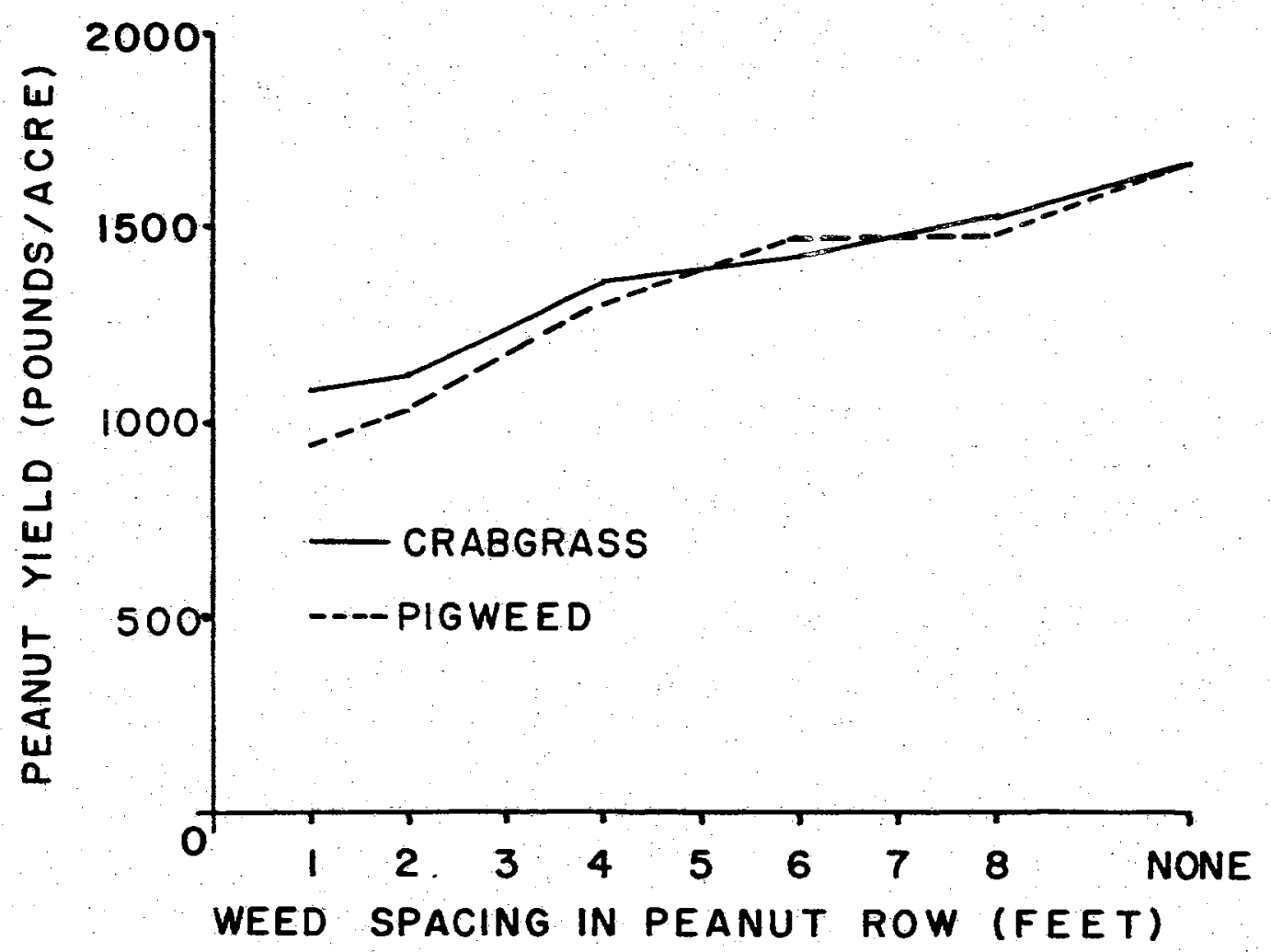

Figure 10. Effects of Two Weed Species at Different Densities on Peanut Yields. Field Study 111 


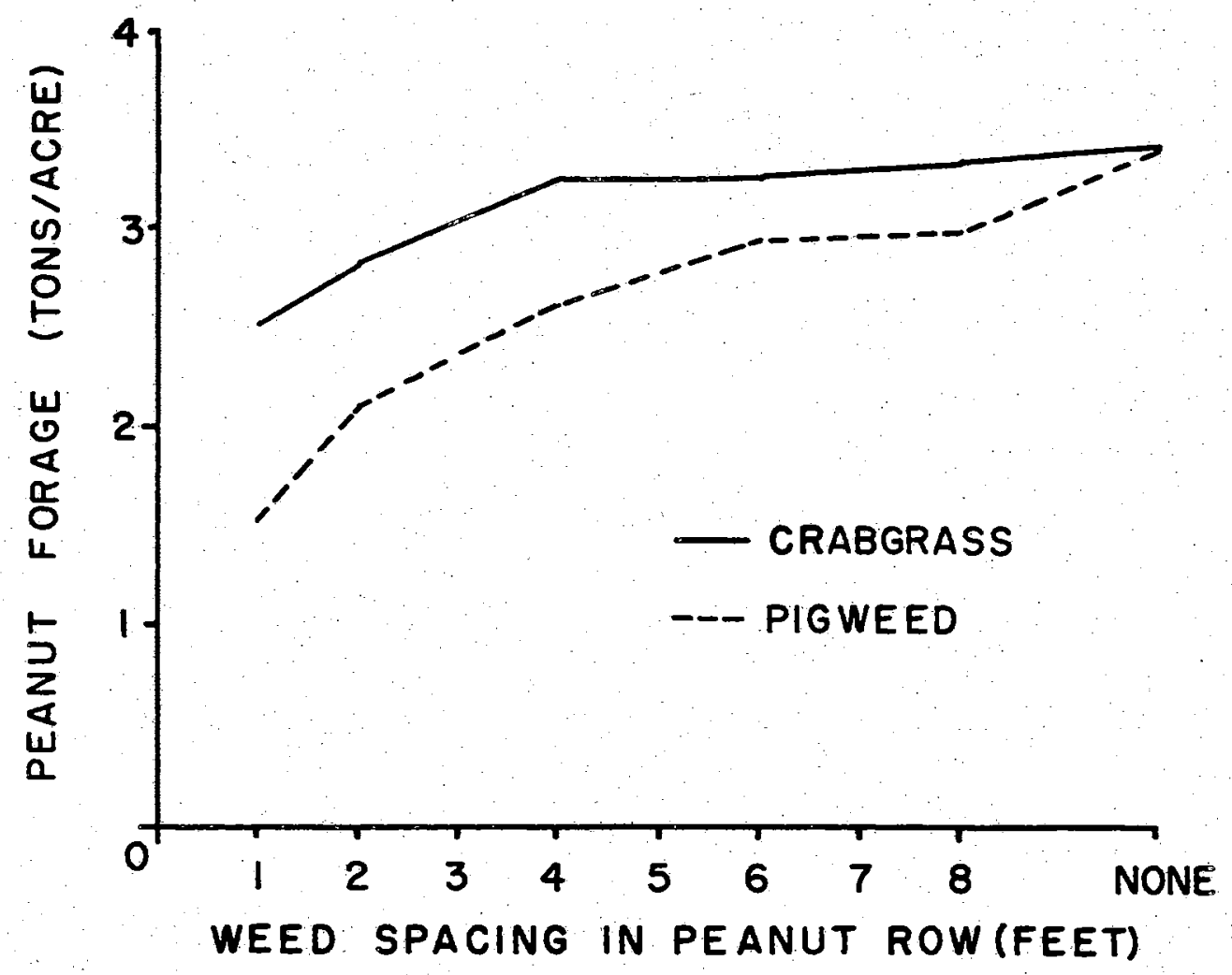

Figure 11. Effects of Two Weed Species at Different Densities on Peanut Forage Yields. Field Study 111 


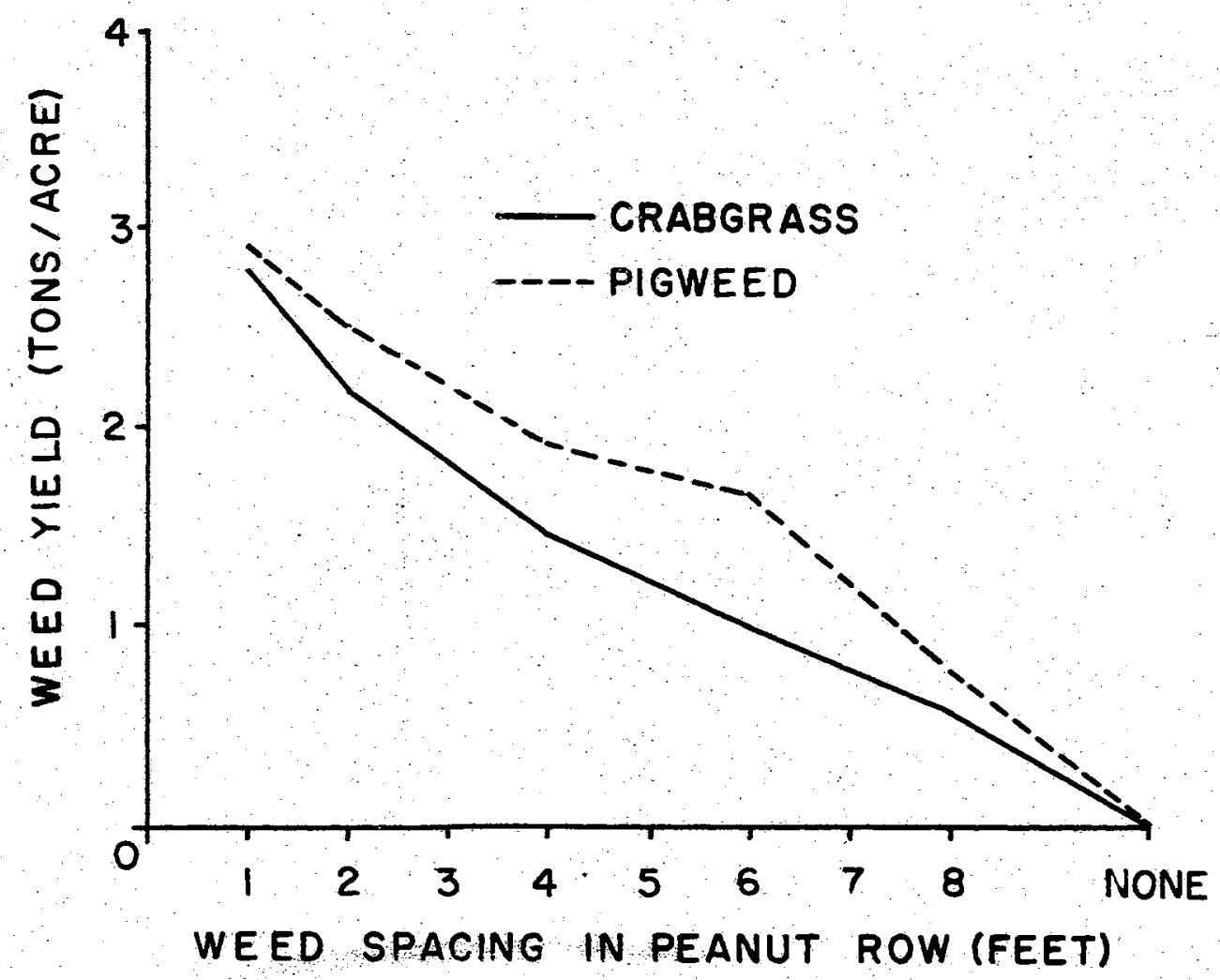

Figure 12. Effects of Weed Density of Two Weed Species on Weed Yields. Field Study 111 
ficantly more top growth than was produced in plots with weeds every 4 feet of peanut row.

\section{Greenhouse Study I}

Peanut nut and forage yields from plants which grew with varied densities of smooth pigweed or large crabgrass in pots showed that a peanut which grew alone produced a significantly higher yield than peanuts which grew in combinations with weeds or other peanuts (Figure 13, 14). Crabgrass, regardless of number in the pot, reduced the nut and forage yields of one peanut (Figure 13A, 14A), and the peanut yield of two peanuts in a pot (Figure 13A) was reduced by 2 or 3 crabgrass per pot. However, the forage yield of two peanuts per pot (Figure 14A) was not reduced by any density of crabgrass. All densities of pigweed significantly reduced the peanut and forage yields (Figure 13, 14) when compared to one peanut grown alone; however, no significant difference in yields of nuts and forage was shown by increasing the number of pigweed per pot. When two peanuts were grown with $1,2,3$, or 4 pigweed, no significant yield reductions of nut (Figure 138) or forage yield of peanuts (Figure 14B) occurred.

The dry matter yield of one pigweed was reduced significantly when more than 3 pigweeds grew in a pot, one peanut in combination with 2 or more pigweeds, and when 2 peanuts in combination with 1 or more pigweeds grew in a pot (Figure 15A). The data shows the yield of pigweed was significantly reduced when grown in a pot with 3 or more plant combinations per pot. The dry matter yield of one crabgrass (Figure 15B) was reduced significantly by 2 or more crabgrass plants, one peanut in combination with one or more crabgrass, and 2 peanuts plus one or more 


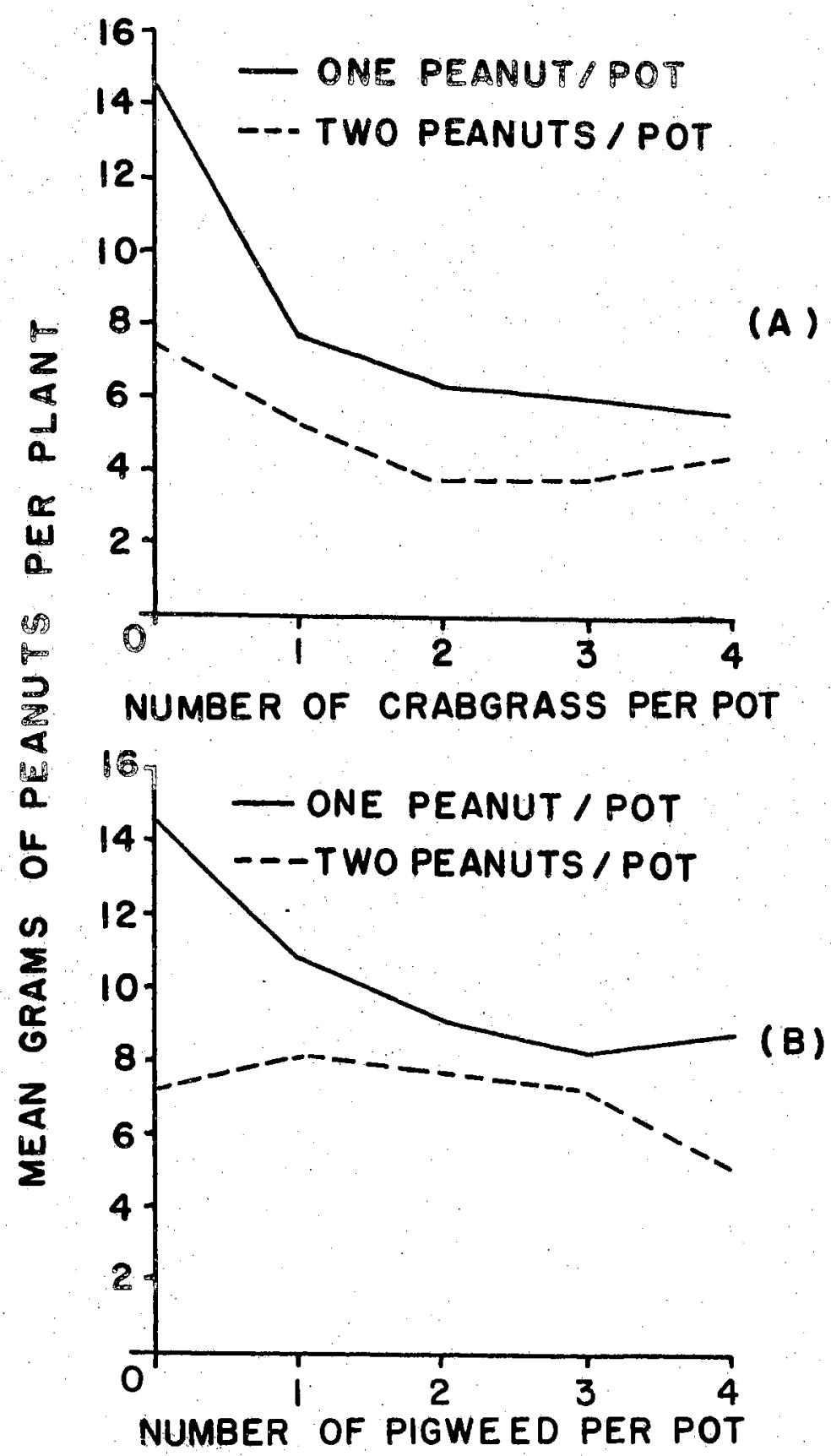

Figure 13. Effects of Two Weed Species at Varied Densities on Peanut Yields. Greenhouse Study I 


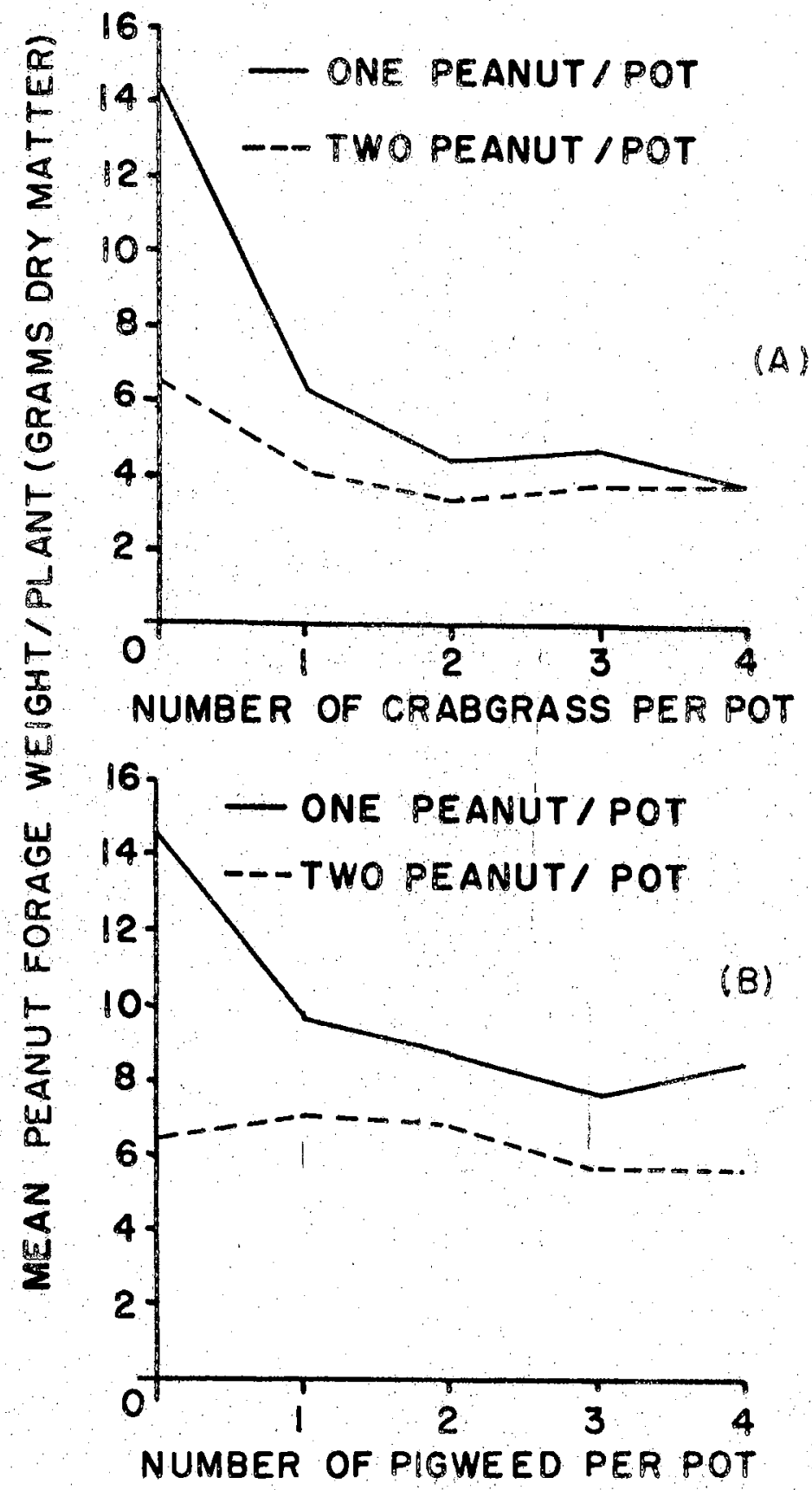

Figure 14. Effects of Two Weed Species at Varied Densities on Peanut Forage Yields. Greenhouse Study 1 


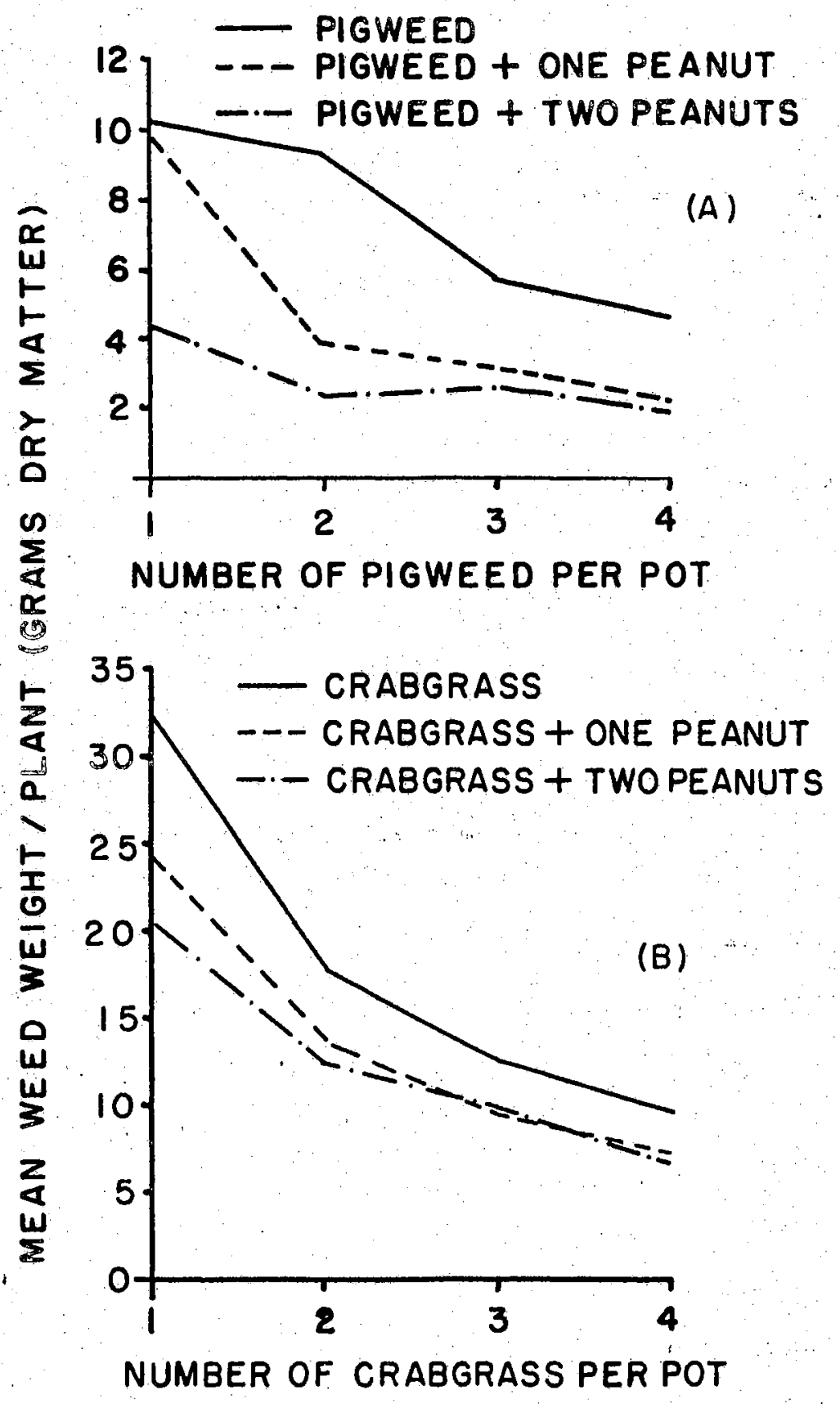

Figure 15. Effects of Competition of Weeds and Peanuts on Weed Dry Weight. Greenhouse Study I 
crabgrass plants per pot. The data from Field Study 111 is contrary to the results of this study in which pigweed reduced the nut yields more than did crabgrass.

\section{Greenhouse Study II}

The dry weight of one peanut plant (Figure 16) was reduced significantly after 6 and 8 weeks of competition by another peanut, a crabgrass or a pigweed plant. Ten and 12 weeks after emergence, only one crabgrass reduced the dry weight of a peanut plant significantly. The results show the dry weight of peanuts was reduced at the same duration of weed competition as peanut yield was reduced in Field Studies 1 and 11 . Dry weight of one crabgrass plant (Figure 17) was reduced after 6 and 8 weeks of competition with another crabgrass plant or peanut plant. After 10 and 12 weeks of competition only another crabgrass plant significantly reduced the weight of one crabgrass plant. The results of this study and Greenhouse Study I show crabgrass able to compete more severely when compared to peanuts or pigweed in the greenhouse.

The dry weight of one pigweed plant (Figure 18) was reduced when pigweed grew in competition with another pigweed plant or peanut after $6,8,10$, and 12 weeks. 


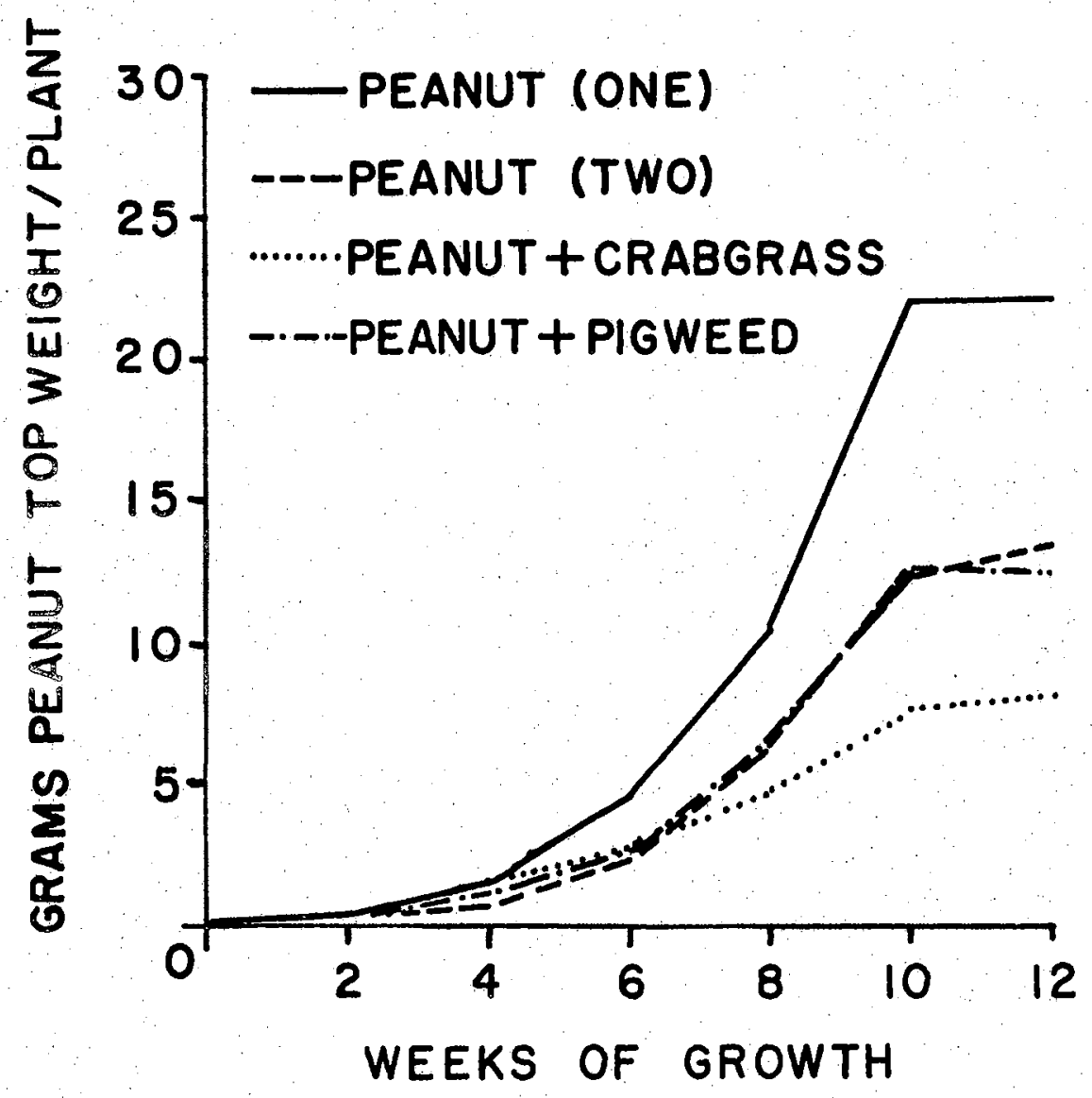

Figure 16. Effects of Peanut and Weed Duration on Dry Weight of Peanut Forage Yield. Greenhouse Study II. 


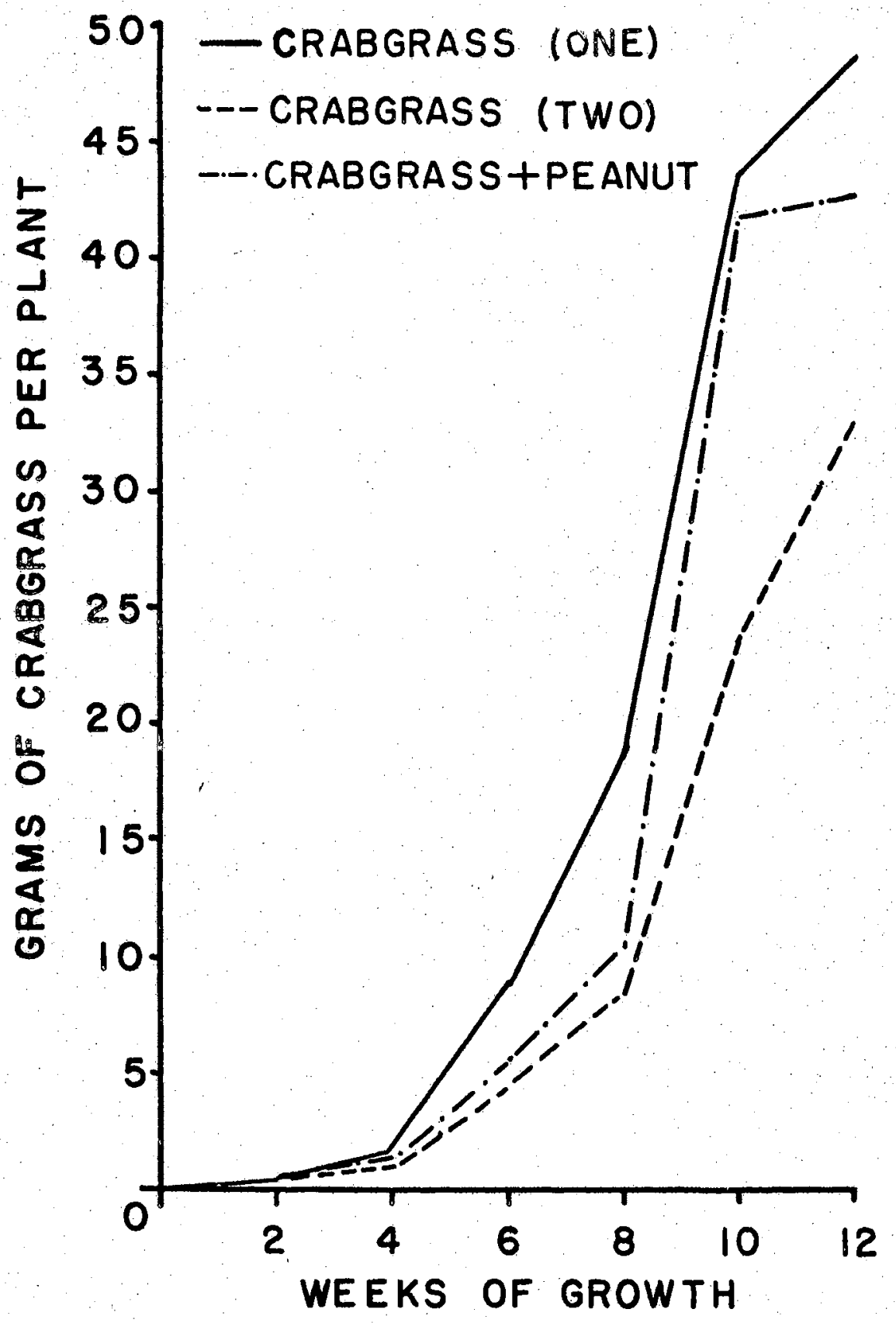

Figure 17. Effects of Peanut and Crabgrass Duration on Dry Weight of Crabgrass Yield.

Greenhouse Study 11 


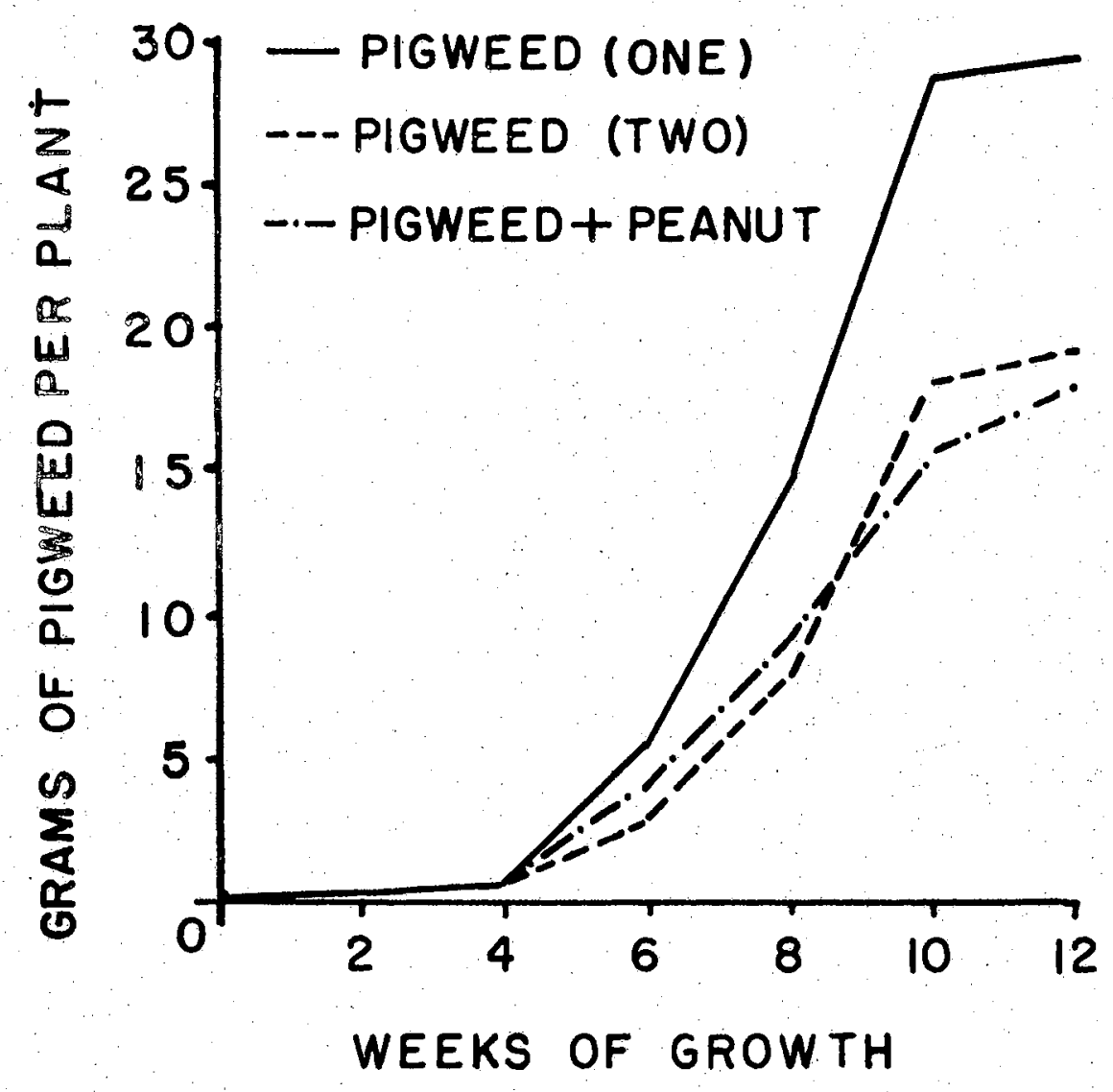

Figure 18. Effects of Peanut and Pigweed Duration on Dry Weight of Pigweed Yield. Greenhouse Study II 


\section{SUMMARY}

Field and greenhouse studies were conducted to investigate the competitive effects of two annual weeds on Spanish peanuts.

Average yield of peanuts was about $2184 \mathrm{lb} / \mathrm{A}$ on weed-free check plots. If peanuts were allowed to grow without weeds for about 6 weeks, the peanut plants could successfully compete with seedling weeds without a nut yield reduction. Thus, it would appear that pre-emergence herbicides must persist for at least 6 weeks to best reduce weed competition in peanuts. Weed control for a longer period may be desired to reduce weed interference with harvesting and curing of peanuts.

Weed growth in peanuts for the first 2 or 3 weeks of the season did not severely affect the yield of the peanuts; however, weeds allowed to remain for periods longer than 3 weeks reduced yields. Competition increased with each additional week of weed growth. These results indicate cultivation and postemergence herbicides will be most beneficial when applied within 3 weeks after planting.

Peanut yields were reduced when one pigweed or crabgrass plant grew every 2 feet apart or in greater densities in the peanut row during the growing season. This data indicates the use of hoeing, cultivation or herbicides would be most beneficial if used when weed density is every 2 feet or greater. However, results of this experiment were probably influenced by an accidental herbicide treatment.

Forage weight of peanuts kept weed-free 4 or 6 weeks was not reduced by weeds which emerged later in growing season. Peanut forage 
weights were reduced after 5 weeks of growth with weeds before removal. Peanut forage weight was reduced by densities of one crabgrass every 1 or 2 feet apart and densities of one pigweed every 1, 2, or 4 feet of peanut row. Pigweed which grew at densities of one weed every 1,2, or 4 feet apart reduced peanut forage yield more than did crabgrass at the same densities. Generally, peanut yields are affected sooner than forage yields from weed competition and pigweed competes slightly stronger at the same densities than does crabgrass.

Weed yield decreased with each week of weeding and was reduced significantly after 3 weeks of weeding. The tonnage of weeds increased as weed densities increased in the peanut row. The tonnage of weeds produced in peanuts which grew 6 feet apart was significantly greater weedfree check.

Weed competition apparently affects soil water in the 27 to 54 inch depth greater than in the 0 to 27 inch soil depth. Weed-free plots had significantly more soil water than weedy plots $55,68,98$, and 110 days after planting in the 27 to 54 inch depth. Plots weeded after 3 or 6 weeks had significantly more soil water all season when compared to weedy plots in 27 to 54 inch depth. Peanuts growing in competition with weeds have less available soil water per plant.

Greenhouse studies showed weeds at all densities reduced the nut and forage yield of peanuts. Crabgrass was shown to be more severe than the pigweed or peanuts in competitive ability. Greenhouse studies were of limited use in peanut competition studies due to limiting root development of plants and different environmental conditions which occurred in greenhouse. 


\section{LITERATURE CITED}

1. Beattie, J.H. 1954. Growing peanuts. U. S. Dept. Agr. Farmers' Bul. 2063.

2. Blackman, G. E. and W. G. Templeman. 1938. The nature of the competition between cereal crops and annual weeds. J. Agri. Sci. $28: 247-271$.

3. Bleasdale, J. K. A. 1960. Studies on plant competition. The biology of weeds. A symposium of the British Ecological Society. John L. Harper (ed.) Blackwell Scientific Publications, Ltd., oxford.

4. Boswell, T. E. 1966. The effect of weed control upon production of Spanish peanuts. Proc. Fourth National Peanut Res. Conf., pp. $57-59$.

5. Brimhal1, P. B. 1964. Effects of annual weeds growing in sugar beets. Masters Thesis, University of Wyoming, Laramie, Wyo.

6. Brimhall, P. B., E. W. Chamberlain and H. P. Alley. 1965. Competition of annual weeds and sugar beets. Weeds 13:33-35.

7. Burnside, 0. C. and G. A. Wicks. 1967, The effects of weed removal treatments on sorghum growth. Weeds 15:204-207.

8. Dawson, J. H. 1964. Competition between irrigated field beans and annual weeds. Weeds 12:206-208.

9. Dawson, J.H. 1965. Competition between irrigated sugar beets and annual weeds. Weeds 13:245-249.

10. Donald, C. M. 1963. Competition among crop and pasture plants. Adv. in Agron. 15:1-144.

11. Greer, A. C. 1966. Weeds costly competitors for nutrients. Plant Food Rev. 12:17.

12. Knake, E. L. and F. W. Slife. 1962. Competition of Setaria faberii with corn and soybeans. Weeds 10:26-29.

13. Knake, E. L. and F. W. Slife. 1965. Giant foxtail seeded at various times in corn and soybeans. Weeds 13:331-334.

14. Moolani, M. K., E. L. Knake and F. W. Slife. 1964. Competition of smooth pigweed with corn and soybeans. Weeds 12:126-128. 
15. Munn, H. H. and T. W. Barnes. 1945. The competition between barley and certain weeds under controlled conditions. Ann. Appl. Biol. 32:252-256.

16. Nelson, D. C. and R. E. Nylund. 1962. Competition between peas grown for processing and weeds: Weeds 10:224-229.

17. Pafford, J. L. 1966. The effects of pigweed on the yield of irrigatèd grain sorghum. Masters Thesis, Texas Technological College, Lubbock, Tex.

18. Staniforth, D.W. and C. R. Weber. 1956. The effect of annual weeds on the growth and yield of soybeans. Agron. J. 48:467-471.

19. Staniforth, D. W. 1958. Soybean-foxtail competition under varying moisture conditions. Agron. J. 50:13-15.

20. Staniforth, D. W. 1961. Response of corn hybrids to yellow foxtail competition. Weeds 9:132-136.

21. Staniforth, D. W. 1965. Competitive effects of three foxtail species on soybeans. Weeds 13:191-193.

22. Steel, R. G. D. and J. H. Torrie. 1960. Principles and procedures of statistics. McGraw-Hill Book Co., Inc., N. Y., 481 p.

23. Swan, D. G. and W. R. Furtick. 1962. Competition of fiddleneck with wheat, Weeds 10:121-123.

24. Vengris, J., W. G. Colby, and M. Drake. 1955. Plant nutrient competition between weeds and corn. Agron. J. 27:213-216.

25. Vengris, J. 1963. The effects of time of seeding on the growth and development of rough pigweed and yellow foxtail. Weeds 11: 48-50.

26. Wilson, C. 1953. Preventing the diseases of peanuts. U. S. Dept. of Agr. Yearbook 448-454.

27. Wilson, H. P. and R. H. Cole. 1966. Morningglory competition in soybeans. Weeds 14:49-51. 
APPENDIX 
TABLE I

MEAN NUMBER OF BLOOMS PER PEANUT PLANT AS INFLUENCED BY THE PERIOD AND LENGTH OF TIME WEEDS WERE ALLOWED TO GROW IN THE PLOTS

47 DAYS AFTER PLANTING. FIELD STUDY 1.

\begin{tabular}{|c|c|c|c|c|c|c|c|c|c|c|c|c|c|c|}
\hline Treatment & & & & & & & & & & & & & Mean & number of blooms \\
\hline Not weeded & & & & & & & & & & & $\cdot$ & & . $\cdot$ & $2.8 \mathrm{~d}$ \\
\hline Weeded for 2 weeks & - & & & & • & • & & & & $\cdot$ & $\cdot$ & & . . & $5.0 \mathrm{~cd}$ \\
\hline Weeded for 3 weeks. & • & & & & $\bullet$ & • & & & & & $\cdot$ & & . . & $8.9 a b$ \\
\hline Weeded for 4 weeks. & • & & & & a & • & & & & . & $\cdot$ & 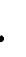 & . . & $9.2 a b$ \\
\hline Weeded for 5 weeks. & • & & & & • & • & & & & 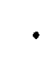 & - & & . . & $9.6 a b$ \\
\hline Weeded for 6 weeks. & & & & & & & & & & & . & 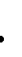 & . $\cdot$ & $8.8 \mathrm{ab}$ \\
\hline Weeded for 8 weeks. & & & & & & & & & & • & $\cdot$ & & $\cdot \cdot$ &.$\quad 11.1 \mathrm{a}$ \\
\hline Weed-free . . . . & & & & & & & & & & · & - & • & . $\cdot$ & $9.0 \mathrm{ab}$ \\
\hline Weeded after 2 weeks & & & & & & & & & & , & - & & $\cdot \cdot$ & $9.4 a b$ \\
\hline Weeded after 3 weeks & & & & & & & & & & 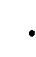 & - & • & $\cdot \cdot$ & $8.9 a b$ \\
\hline Weeded after 4 weeks & & & & & & & & 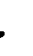 & & 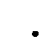 & - & 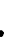 & $\cdot \cdot$ & $7.2 a b c$ \\
\hline Weeded after 5 weeks & • & & & & & & & & & 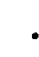 & 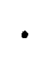 & & . . & $5.2 \mathrm{bcd}$ \\
\hline Weeded after 6 weeks & & & & & & & & & & & ${ }^{\circ}$ & & . & $4.2 \mathrm{~cd}$ \\
\hline Weeded after 7 weeks & & & & & & & & & & & ${ }^{\circ}$ & & - . & $2.8 \mathrm{~d}$ \\
\hline Weeded after 8 weeks & & & & & & & & & & & & & . & $2.6 \mathrm{~d}$ \\
\hline
\end{tabular}

${ }^{a}$ Numbers followed by different letters are significantly different at the $95 \%$ level of probability. 
TABLE II

YIELD OF PEANUTS (NUTS AND FORAGE) AND OF WEEDS AS INFLUENCED BY THE PERIOD AND LENGTH OF TIME WEEDS WERE ALLOWED TO GROW IN THE PLOTS

\begin{tabular}{|c|c|c|c|c|c|c|c|}
\hline Treatment & $\begin{array}{r}\text { Nut } \\
1966\end{array}$ & $\begin{array}{r}\text { Yield }{ }^{a}(1 b / A) \\
1967\end{array}$ & $\begin{array}{l}\text { Forage } \\
1966\end{array}$ & $\begin{aligned} \text { Yield }^{a} & (T / A) \\
& 1967\end{aligned}$ & $\begin{array}{l}\text { Weed } \\
1966\end{array}$ & Yield & $\begin{array}{r}(T / A) \\
1967\end{array}$ \\
\hline Not weeded & 1479 & $67 \mathrm{e}$ & $0.6 \mathrm{e}$ & $0.1 \mathrm{~g}$ & $2.6 \mathrm{a}$ & & $5.2 \mathrm{a}$ \\
\hline Weeded for 2 weeks & $273 f$ & $261^{\circ} \mathrm{e}$ & $0.9 \mathrm{e}$ & $0.5 \mathrm{fg}$ & $2.3 \mathrm{a}$ & & $3.4 a b$ \\
\hline Weeded for 3 weeks & $360 f$ & $844 \mathrm{~cd}$ & $1.3 \mathrm{~d}$ & $1.5 \mathrm{de}$ & $1.9 \mathrm{a}$ & & $2.4 \mathrm{bc}$ \\
\hline Weeded for 4 weeks & $603 c$ & $1151 \mathrm{c}$ & $2.1 \mathrm{c}$ & $2.0 \mathrm{~cd}$ & $1.8 a$ & & $0.8 \mathrm{~cd}$ \\
\hline Weeded for 5 weeks & 1272 & $1868 \mathrm{ab}$ & $2.7 \mathrm{~b}$ & $3.5 \mathrm{a}$ & $0.3 \mathrm{~b}$ & & $0.3 d$ \\
\hline Weeded for 6 weeks & $1664 \mathrm{~b}$ & $1958 a b$ & $3.4 \mathrm{~b}$ & $3.7 \mathrm{a}$ & $0.2 b$ & & $0.1 \mathrm{~d}$ \\
\hline Weeded for 8 weeks & $1864 \mathrm{~b}$ & $1995 a b$ & 3.8 a & $3.8 \mathrm{a}$ & $0.0 \mathrm{~b}$ & & $0.3 d$ \\
\hline Weed-free & $2083 a$ & 2287 a & 3.9 a & $3.7 \mathrm{a}$ & $0.0 \mathrm{~b}$ & & $0.0 \mathrm{~d}$ \\
\hline Weeded after 2 weeks & $1776 \mathrm{~b}$ & $2220 a b$ & $3.8 \mathrm{a}$ & $3.5 \mathrm{ab}$ & -- & & -- \\
\hline Weeded after 3 weeks & $1648 \mathrm{~b}$ & $2167 a b$ & $3.6 a$ & $3.5 \mathrm{ab}$ & -- & & -- \\
\hline Weeded after 4 weeks & $1615 \mathrm{~b}$ & $1794 a b$ & $3.5 \mathrm{a}$ & $3.5 \mathrm{ab}$ & -- & & -- \\
\hline Weeded after 5 weeks & 1589 & $1666 \mathrm{~b}$ & $3.6 \mathrm{a}$ & $3.3 \mathrm{ab}$ & -- & & -- \\
\hline Weeded after 6 weeks & 1078 & $1009 c$ & $3.0 \mathrm{~b}$ & $2.5 b c$ & -- & & -- \\
\hline Weeded after 7 weeks & 962 & $448 \mathrm{de}$ & $2.2 \mathrm{c}$ & $1.2 \mathrm{def}$ & -- & & -- \\
\hline Weeded after 8 weeks & $652 \epsilon$ & .2393 & $1.3 \mathrm{~d}$ & $0.9 \mathrm{efg}$ & -- & & -- \\
\hline
\end{tabular}

Weeded after 8 weeks

a Numbers within level of probability. 
TABLE \|I

EFFECTS OF ANNUAL WEED DURATION ON INCHES OF SOIL WATER IN SOIL

\begin{tabular}{|c|c|c|c|c|c|c|c|c|}
\hline Treatment & 49 & 55 & 68 & $\begin{array}{l}\text { Days after } \\
\quad 77\end{array}$ & $\begin{array}{c}\text { planting } \\
84\end{array}$ & 91 & 98 & 110 \\
\hline & \multicolumn{8}{|c|}{ Inches of soil water in 0 to 27 inch soil depth ${ }^{a}$} \\
\hline Not weeded & $3.9 a$ & $3.3 a$ & $3.1 \mathrm{a}$ & $3.1 \mathrm{a}$ & $2.9 b$ & $3.3 \mathrm{a}$ & $3.0 \mathrm{a}$ & 4.5 a \\
\hline Weeded for 3 weeks & $4.4 a$ & $3.4 a$ & $3.3 a$ & $3.3 \mathrm{a}$ & $3.1 \mathrm{~b}$ & 3.9 a & $3.2 \mathrm{a}$ & $5.3 \mathrm{a}$ \\
\hline Weeded for 6 weeks & $5.5 a$ & $4.9 a$ & $4.5 \mathrm{a}$ & $4.0 a$ & $3.3 \mathrm{ab}$ & $4.3 a$ & $3.7 \mathrm{a}$ & $5.5 a$ \\
\hline Weed-free & $5.0 a$ & $4.2 a$ & $3.8 \mathrm{a}$ & $3.6 \mathrm{a}$ & $3.6 a$ & $4.4 \mathrm{a}$ & $3.7 \mathrm{a}$ & $5.7 \mathrm{a}$ \\
\hline Weeded after 3 weeks & $5.1 a$ & $4.8 a$ & $4.5 a$ & $4.0 \mathrm{a}$ & $3.6 a$ & $4.4 a$ & 3.9 a & $5.0 \mathrm{a}$ \\
\hline \multirow[t]{2}{*}{ Weeded after 6 weeks } & $4.8 a$ & $4.4 a$ & $4.0 a$ & $4.0 a$ & 4.1 & $4.7 a$ & $3.9 \mathrm{a}$ & $5.6 a$ \\
\hline & \multicolumn{8}{|c|}{ Inches of soil water in 27 to 54 inch soil depth ${ }^{a}$} \\
\hline Not weeded & $4.1 \mathrm{~b}$ & $3.8 \mathrm{~b}$ & $3.6 \mathrm{c}$ & $3.4 \mathrm{c}$ & $3.3 \mathrm{~b}$ & $3.3 \mathrm{~b}$ & $3.0 \mathrm{c}$ & $3.0 \mathrm{c}$ \\
\hline Weeded for 3 weeks & $4.8 a b$ & $4.5 a b$ & $4.2 \mathrm{bc}$ & $3.7 \mathrm{bc}$ & $3.5 a b$ & $3.5 \mathrm{~b}$ & $3.4 \mathrm{bc}$ & $3.3 \mathrm{bc}$ \\
\hline Weeded for 6 weeks & $5.3 a$ & $5.4 a$ & $5.3 a b$ & $5.0 \mathrm{ab}$ & $4.8 a b$ & $4.6 a b$ & $4.4 \mathrm{ab}$ & $4.3 a b$ \\
\hline Weed-free & $5.0 \mathrm{ab}$ & $4.8 a$ & $5.0 \mathrm{ab}$ & $4.6 \mathrm{abc}$ & $4.5 a b$ & $4.5 \mathrm{ab}$ & $4.3 \mathrm{ab}$ & $4.2 \mathrm{ab}$ \\
\hline Weeded after 3 weeks & $5.4 a$ & $5.4 a$ & $5.4 a b$ & $5.2 a$ & $5.0 \mathrm{a}$ & $5.0 a$ & $4.8 \mathrm{a}$ & $4.7 \mathrm{a}$ \\
\hline Weeded after 6 weeks & $5.4 \mathrm{a}$ & $5.4 a$ & $5.4 a$ & $5.3 a$ & $5.2 \mathrm{a}$ & $5.0 a$ & $4.6 a$ & $4.9 a$ \\
\hline
\end{tabular}

a Numbers within one column of each soil depth followed by different letters are significantly different at the $95 \%$ probability level. 
TABLE IV

EFFECTS OF ANNUAL WEED DURATION ON INCHES OF SOIL WATER IN 0 to 54 INCH SOIL DEPTH

\begin{tabular}{|c|c|c|c|c|c|c|c|c|}
\hline \multirow[b]{2}{*}{ Treatment } & \multirow[b]{2}{*}{49} & \multirow[b]{2}{*}{55} & \multirow[b]{2}{*}{68} & \multicolumn{3}{|c|}{ Days after planting } & \multirow[b]{2}{*}{98} & \multirow[b]{2}{*}{110} \\
\hline & & & & 77 & 84 & 91 & & \\
\hline Not weeded & $8.0 \mathrm{~b}$ & $7.1 \mathrm{~b}$ & $6.7 \mathrm{~b}$ & $6.5 c$ & $6.2 \mathrm{~b}$ & 6.6 a & $6.0 \mathrm{~b}$ & $7.5 \mathrm{~b}$ \\
\hline Weeded for 3 weeks & $9.1 \mathrm{ab}$ & $7.8 \mathrm{ab}$ & $7.5 \mathrm{ab}$ & $7.0 \mathrm{bc}$ & $6.6 \mathrm{ab}$ & $7.4 \mathrm{a}$ & $6.5 \mathrm{ab}$ & $8.6 \mathrm{ab}$ \\
\hline Weeded for 6 weeks & $10.8 \mathrm{a}$ & $10.2 a$ & $9.7 \mathrm{a}$ & $9.0 \mathrm{abc}$ & $8.1 \mathrm{ab}$ & $8.7 \mathrm{a}$ & $8.0 \mathrm{ab}$ & $9.8 \mathrm{a}$ \\
\hline Weed-free & 10.1 a & $9.0 \mathrm{ab}$ & $8.8 \mathrm{ab}$ & $8.3 \mathrm{abc}$ & $8.1 a b$ & 8.9 a & $8.0 \mathrm{ab}$ & $9.9 \ldots$ \\
\hline Weeded after 3 weeks & $10.5 \mathrm{a}$ & $10.2 \mathrm{a}$ & 9.8 a & $9.2 a b$ & $8.6 a$ & 9.5 a & $8.7 \mathrm{a}$ & $9.7 \mathrm{a}$ \\
\hline Weeded after 6 weeks & 10.1 a & 9.8 a & $9.5 a b$ & $9.3 \mathrm{a}$ & $9.3 \mathrm{a}$ & $9.8 a$ & $8.5 \mathrm{ab}$ & 10.5 a \\
\hline
\end{tabular}

${ }^{a}$ Numbers within one column followed by different letters are significantly different at the $95 \%$ probability level. 
TABLE $V$

YIELD OF PEANUTS (NUTS AND FORAGE) AND OF WEEDS AS INFLUENCED BY TWO WEED SPECIES AT VARYING DENSITIES

\begin{tabular}{|c|c|c|c|}
\hline Treatment & Nut Yield $(1 \mathrm{~b} / A)$ & Forage Yield ${ }^{a}(T / A)$ & Weed Yield ${ }^{a}(T / A)$ \\
\hline One crabgrass per 1 foot & $1089 \mathrm{cde}$ & $2.5 \mathrm{cde}$ & $2.8 a b$ \\
\hline One crabgrass per 2 feet & 1123 bcde & $2.8 \mathrm{bc}$ & $2.2 \mathrm{abcd}$ \\
\hline One crabgrass per 4 feet & $1367 \mathrm{abcd}$ & $3.3 \mathrm{ab}$ & $1.5 \mathrm{cde}$ \\
\hline One crabgrass per 6 feet & $1438 a b c$ & $3.3 \mathrm{ab}$ & 1.1 de \\
\hline One crabgrass per 8 feet & 1525 a & $3.3 \mathrm{ab}$ & 0.6 ef \\
\hline Weed-free & 1664 a & 3.4 a & $0.0 f$ \\
\hline One pigweed per 8 feet & $1481 a b$ & $3.0 a b c$ & $0.8 \mathrm{ef}$ \\
\hline One pigweed per 6 feet & $1472 a b$ & $2.9 a b c$ & 1.7 bcde \\
\hline One pigweed per 4 feet & $1307 \mathrm{abcd}$ & $2.6 \mathrm{~cd}$ & 1.9 abcd \\
\hline One pigweed per 2 feet & $1037 \mathrm{de}$ & $2.1 \mathrm{def}$ & $2.5 \mathrm{abc}$ \\
\hline One pigweed per 1 foot & 941 e & $1.6 f$ & $2.9 \mathrm{a}$ \\
\hline
\end{tabular}

a Numbers within one column followed by different letters are significantly different at the $95 \%$ probability level. 
TABLE VI

MEAN NUT AND FORAGE PEANUT WEIGHT (GRAMS/PLANT) AS

INFLUENCED BY TWO WEED SPECIES AT VARYING

DENSITIES. GREENHOUSE STUDY I

\begin{tabular}{lll}
\hline Treatment & Nut Yield & Forage Yiéld \\
\hline One peanut & 14.6 & 14.7 \\
One peanut and one pigweed & 10.9 a & 9.8 a \\
One peanut and two pigweed & 9.1 ab & 8.9 abc \\
One peanut and three pigweed & 8.1 abcd & 7.5 abcde \\
One peanut and four pigweed & 8.7 abc & 8.5 abcd \\
One peanut and one crabgrass & 7.7 abcde & 6.3 abcdef \\
Ore peanut and two crabgrass & 6.2 bcdef & 4.5 ef \\
One peanut and three crabgrass & 6.0 bcdef & 4.7 def \\
One peanut and four crabgrass & 5.5 cdef & 3.9 ef \\
Two peanuts & 7.3 abcde & 6.6 abcdef \\
Two peanuts and 1 pigweed & 8.2 abcd & 7.1 abcdef \\
Two peanuts and 2 pigweed & 7.5 abcde & 6.8 abcdef \\
Two peanuts and 3 pigweed & 7.1 abcde & 5.6 cdef \\
Two peanuts and 4 pigweed & 5.0 def & 5.7 cdef \\
Two peanuts and 1 crabgrass & 5.3 def & 4.0 ef \\
Two peanuts and 2 crabgrass & $3.4 \mathrm{f}$ & 3.8 ef \\
\hline
\end{tabular}

a Numbers within one column followed by different letters are significantly different at the $95 \%$ probability level. 


\section{TABLE VII}

MEAN FORAGE WEIGHT (GRAMS/PLANT) OF SMOOTH PIGWEED AS INFLUENCED BY GROWTH WITH

PEANUTS. GREENHOUSE STUDY I

\begin{tabular}{lc}
\hline Treatment & Forage Yield \\
\hline 1 pigweed & $10.1 \mathrm{a}$ \\
2 pigweed & $9.5 \mathrm{ab}$ \\
3 pigweed & 5.7 bcdef \\
4 pigweed & 4.5 def \\
1 pigweed and 1 peanut & 10.0 a \\
2 pigweed and 1 peanut & 4.0 def \\
3 pigweed and 1 peanut & 3.1 def \\
4 pigweed and 1 peanut & $2.2 \mathrm{f}$ \\
1 pigweed and 2 peanuts & $4.3 \mathrm{def}$ \\
2 pigweed and 2 peanuts & $2.3 \mathrm{f}$ \\
3 pigweed and 2 peanuts & 2.7 ef \\
4 pigweed and 2 peanuts & $2.0 \mathrm{f}$ \\
\hline
\end{tabular}

a Numbers followed by different letters are significantly different at the $95 \%$ probability level. 


\section{TABLE VIII}

MEAN CRABGRASS FQRAGE WEIGHT (GRAMS/PLANT) AS

INFLUENCED BY GROWTH WITH PEANUTS AND

CRABGRASS , GREENHOUSE STUDY I

\begin{tabular}{lc}
\hline Treatment & Forage Yield ${ }^{a}$ \\
\hline 1 crabgrass & 32.1 \\
2 crabgrass & $17.8 \mathrm{a}$ \\
3 crabgrass & $12.7 \mathrm{bc}$ \\
4 crabgrass & $9.8 \mathrm{~cd}$ \\
1 crabgrass and 1 peanut & 24.0 \\
2 crabgrass and 1 peanut \\
3 crabgrass and 1 peanut \\
4 crabgrass and 1 peanut & $14.0 \mathrm{~b}$ \\
1 crabgrass and 2 peanuts & $9.5 \mathrm{cde}$ \\
2 crabgrass and 2 peanuts & $7.3 \mathrm{de}$ \\
3 crabgrass and 2 peanuts & $20.8 \mathrm{a}$ \\
4 crabgrass and 2 peanuts & $12.6 \mathrm{bc}$ \\
\hline
\end{tabular}

a Numbers followed by different letters are significantly different at the $95 \%$ probability level. 
TABLE IX

EFFECTS OF TIME ON PEANUT, CRABGRASS AND PIGUEED FORAGE WEIGHT ${ }^{\mathrm{a}}$ (GRAMS/PLANT)

GROWN AT DIFFERENT DENSITIES. GREENHOUSE STUDY 11

\begin{tabular}{|c|c|c|c|c|c|c|}
\hline Treatment & 2 & 4 & $\begin{array}{l}\text { Weeks } \\
6\end{array}$ & $\begin{array}{c}\text { after planting } \\
8\end{array}$ & 10 & 12 \\
\hline 1 peanut & $0.4 a$ & $1.5 \mathrm{a}$ & $4.3 \mathrm{bc}$ & $10.4 \mathrm{a}$ & $21.8 \mathrm{bcd}$ & $21.6 \mathrm{~cd}$ \\
\hline 2 peanuts & $0.4 a$ & $1.2 \mathrm{a}$ & $2.6 \mathrm{de}$ & $6.3 \mathrm{bc}$ & 12.2 de & $13.4 \mathrm{de}$ \\
\hline 1 peanut with 1 crabgrass & $0.4 \mathrm{a}$ & $1.4 \mathrm{a}$ & $2.7 \mathrm{de}$ & $4.8 \mathrm{c}$ & $7.6=\mathrm{e}$ & $7.6 \mathrm{e}$ \\
\hline 1 peanut with 1 pigweed & $0.3 a$ & 0.9 a & $2.1 e$ & $6.0 \mathrm{bc}$ & $12.5 \mathrm{de}$ & 12.1 de \\
\hline 1 crabgrass & $0.1 \mathrm{~b}$ & $1.4 \mathrm{a}$ & 8.4 & 18.6 & $43.3 \mathrm{a}$ & $48.6 \mathrm{a}$ \\
\hline 2 crabgrass & $0.1 \mathrm{~b}$ & $1.0 \mathrm{a}$ & $4.5 a b c$ & $8.3 \mathrm{ab}$ & $23.2 \mathrm{bc}$ & $32.7 \mathrm{~b}$ \\
\hline 1 crabgrass with 1 peanut & $0.1 \mathrm{~b}$ & $1.1 \mathrm{a}$ & $5.4 a$ & 10.2 a & 41.9 a & 42.3 a \\
\hline 1 pigweed & $0.03 \mathrm{~b}$ & 0.8 a & $5.2 a b$ & 14.6 & $28.9 b$ & $29.2 b c$ \\
\hline 2 pigweed & $0.03 \mathrm{~b}$ & $0.8 \mathrm{a}$ & $2.8 \mathrm{de}$ & $7.7 \mathrm{abc}$ & $18.1 \mathrm{~cd}$ & $19.1 d$ \\
\hline I pigweed with 1 peanut & $0.02 \mathrm{~b}$ & $0.9 a$ & $3.8 \mathrm{~cd}$ & $9.1 \mathrm{ab}$ & 15.6 cde & $17.9 d$ \\
\hline
\end{tabular}

a Numbers within one column followed by different letters are significantly different at the $95 \%$ probability level. 


\author{
VITA / \\ Loyd Vernon Hill \\ Candidate for the Degree of \\ Master of Science
}

Thesis: COMPETITIVE EFFECTS OF ANNUAL WEEDS ON SPANISH PEANUTS

Major Field: Agronomy

Bographical:

Personal Data: Born near Tribune, Kansas, June 1, 1934, the son of Carl H. and Minnie D. Hill.

Education: Attended grade school at Amorita and Manchester, Oklahoma; graduated from Manchester High School in 1952; received the Bachelor of Science degree from the Oklahoma State University with a major in Agronomy in May, 1956; completed requirements for the Master of Science degree in August, 1969.

Professional experience: Entered the United States Air Force in 1956 and served as an officer for nine years; served as soil scientist for Soil Conservation Service 1965-1966; served as graduate assistant and research technician while completing requirements for Master of Science degree from Oklahoma State University.

Member of: Weed Science Society of America and Sigma Xi. 